\author{
This article has been accepted for publication in the Journal of Cross \\ Cultural Psychology (Dec, 2021), published by Sage.
}

\title{
Gender equality and maternal burnout: a 40-country study
}

\author{
Corresponding author: Isabelle Roskam, isabelle.roskam@uclouvain.be \\ ORCID 0000-0002-1449-113 \\ UCLouvain, Department of Psychology, Place Cardinal Mercier 10, B-1348 Louvain-la-Neuve, Belgium
}

Isabelle Roskam' (coordinator and corresponding author), Laura Gallée 'Joyce Aguiar ${ }^{2}$, Ege Akgun $^{3}$, Andrew Arena ${ }^{4}$, Gizem Arikan ${ }^{5}$, Kaisa Aunola ${ }^{6}$, Michel Bader ${ }^{7}$, Elizabeth J. Barham ${ }^{8}$, Eliane Besson ${ }^{9}$, Wim Beyers ${ }^{10}$, Emilie Boujut ${ }^{11}$, Maria Elena Brianda' ${ }^{1-12}$, Anna Brytek-Matera ${ }^{13}$, Noémie Carbonneau ${ }^{14}$, Filipa César ${ }^{2}$, Bin-Bin Chen ${ }^{15}$, Géraldine Dorard ${ }^{10}$, Luciana Carla dos Santos Elias ${ }^{16}$, Sandra Dunsmuir ${ }^{17}$, Natalia Egorova ${ }^{18}$, Nicolas Favez ${ }^{19}$, Anne-Marie Fontaine ${ }^{2}$, Heather Foran ${ }^{20}$, Julia Fricke ${ }^{21}$, Kaichiro Furutani ${ }^{22}$, Myrna Gannagé , Maria Gaspar ${ }^{23}$, Lucie Godbout $^{14}$, Amit Goldenberg ${ }^{2425}$, James J. Gross ${ }^{25}$, Maria Ancuta Gurza ${ }^{26}$, Muhammad Aamir Hashmi $^{27}$, Mai Helmy ${ }^{2829}$, Mai Trang Huynh ${ }^{30}$, Emerence Kaneza ${ }^{31}$, Taishi Kawamoto ${ }^{32}$, Nassima Kellou $^{33}$, Goran Knezevic ${ }^{34}$, Ljiljana B. Lazarevic ${ }^{34}$, Sarah Le Vigouroux ${ }^{35}$, Astrid LebertCharron" ${ }^{11}$ Vanessa Leme ${ }^{36}$, Gao-Xian Lin', Carolyn MacCann ${ }^{37}$, Denisse Manrique-Millones ${ }^{38}$, Marisa Matias $^{2}$, María Isabel Miranda-Orrego ${ }^{39}$, Marina Miscioscia ${ }^{40}$, Clara Morgades-Bamba ${ }^{41}$, Seyyedeh Fatemeh Mousavi ${ }^{42}$, Badra Moutassem-Mimouni ${ }^{33}$, Ana Muntean ${ }^{43}$, Hugh Murphy ${ }^{20}$, Alexis Ndayizigiye ${ }^{31}$, Josué Ngnombouowo Tenkue ${ }^{44}$, Sally Olderbak ${ }^{45}$, Sophie Ornawka ${ }^{14}$, Daniela Oyarce-Cadiz ${ }^{46}$, Pablo A. Pérez-Díaz ${ }^{47}$, Konstantinos V. Petrides ${ }^{17}$, Claudia PinedaMarinn $^{48}$, Alena Prikhidko ${ }^{49}$, Fernando Salinas-Quiroz ${ }^{50}$, Raquel Sánchez-Rodríguez ${ }^{51.52}$, Ainize Sarrionandia ${ }^{53}$, Céline Scola ${ }^{54}$, Alessandra Simonelli ${ }^{55}$, Bart Soenens ${ }^{10}$, Emma Sorbring ${ }^{56}$, Matilda Sorkkila $^{6}$, Charlotte Schrooyen ${ }^{10}$, Elena Stănculescu ${ }^{57}$, Elena Starchenkova ${ }^{58}$, Dorota Szczygiel ${ }^{59}$, Thi Minh Thuy Tri ${ }^{30}$, Mélissa Tremblay ${ }^{14}$, A. Meltem Ustundag-Budak ${ }^{61}$, Maday Valdés Pacheco $^{62}$, Hedwig van Bakel ${ }^{{ }^{9}}$, Lesley Verhofstadt ${ }^{10}$, Jaqueline Wendland", Saengduean Yotanyamaneewong ${ }^{63}$, Moïra Mikolajczak ${ }^{1}$

UCLouvain, Department of Psychology, Place Cardinal Mercier 10, B-1348 Louvain-la-Neuve, Belgium. University of Porto, Faculty of Psychology and Educational Sciences, Center for Psychology, Rua Alfredo Allen, s/n, 4200-135 Porto, Portugal.

${ }^{3}$ Ankara University, Department of Preschool Education, Egitim Bilimleri Fakultesi Cebeci, 06590 Ankara, Turkey.

University of New South Wales, The Black Dog Institute, Hospital Rd, Randwick, NSW, 2031, Australia. Ozyegin University, Department of Psychology, Nisantepe Mah Orman Sok, 34794 Cekmekoy, Turkey. University of Jyväskylä, Department of Psychology, P.O. Box 35, 40014 University of Jyväskylä, Finland. University of Lausanne(UNIL), Department DP CHUV, Avenue Pierre-Decker 5, CH 1011 Lausanne, Switzerland.

FFederal University in São Carlos, Department of Psychology, Rodovia Washington Luís km 235, 13564-180 São Carlos, Brazil.

'Saint-Joseph University, Department of Psychology, Rue de Damas, B.P. 17-5208- Mar Mikhael, Beyrouth 11042020, Lebanon.

"Ghent University, Faculty of Psychology and Educational Sciences, Henri Dunantlaan 2, 9000 Gent, Belgium. 
"Université de Paris, Laboratoire de Psychopathologie et Processus de Santé, F-92100 Boulogne Billancourt, France.

"Université de Liège, Faculté de Psychologie, Logopédie et Sciences de l'Education, Place des Orateurs, 2, 4000 Liège, Belgium.

University of Wroclaw, Institute of Psychology, Dawida 1, 50-527 Wroclaw, Poland.

"Université du Québec à Trois-Rivières, Département de Psychologie, 3351 Boulevard Des Forges, Trois-

Rivières, Québec, Canada.

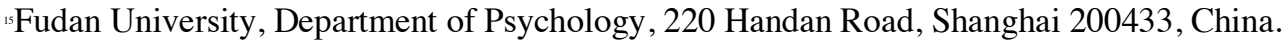

${ }^{\circledR}$ University of São Paulo, Department of Psychology, Avenue. Dr. Renato Pagano 416-A, Cravinhos, São Paulo, Brazil.

"University College London, Division of Psychology and Language Sciences, 26 Bedford Way, London WC1H 0AP, United Kingdom.

"EPSM de l'Agglomération Lilloise, Psychiatrie adulte, 1 Rue de Lommelet, 59350 Saint-André-lez-Lille, France.

"University of Geneva, Department of Psychology, Uni Mail, 40 Bvd du Pont d'Arve, 1205 Geneva, Switzerland. ${ }^{2}$ Alpen-Adria-Universität Klagenfurt, Abteilung für Gesundheitspsychologie, Universitätsstraße 65-67, 9020

Klagenfurt, Austria.

${ }^{2}$ Charité-Universitätsmedizin Berlin, Institute for Social Medicine, Epidemiology and Health Economics,

Luisenstr. 57, 10117 Berlin, Germany.

${ }^{2}$ Hokkai-gakuen University, Faculty of Business Administration, 4-1-40, Asahimachi, Toyohiraku, Sapporo, Japan.

${ }^{2}$ University of Coimbra, Centre for Social Studies, Faculty of Psychology and Educational Sciences, Rua do Colégio Novo, Ap.6153, 3000-115 Coimbra, Portugal.

${ }^{2}$ Harvard University, Harvard Business School139 Oxford St, Cambridge, MA, USA.

${ }^{2}$ Stanford University, Department of Psychology, Stanford University, Stanford, CA 94305-2130, USA.

${ }^{2}$ DGASPC Timis, Department of Psychology, Pta Regina Maria Nr.3, Timisoara, Romania.

${ }^{2}$ University of the Punjab, Institute of Education and Research, Lahore, Pakistan.

${ }^{2}$ Menoufia university, Psychology department, Faculty of Arts, Gamal abdel naser street- Shebin el kom -

Menoufia governorate, Egypt.

${ }^{2}$ Sultan Qaboos university, Psychology department, College of Education, Oman, Egypt.

«University of Social Sciences and Humanities, HoChiMinh National University, Faculty of Psychology, $10-12$

Dinh Tien Hoang, Ho Chi Minh City, Vietnam.

"Clinique de l'Education et de la Psychothérapie, Robero I, 6136 Bujumbura, Burundi

"Chubu University, College of Humanities, Department of Psychology, 1200 Matsumoto-cho, Kasugai, Aichi 487-8501, Japan.

Université Mohamed Benahmed Oran2, Department of Psychology, 109 rue de Mostaganem, Oran, Algeria. University of Belgrade, Faculty of Philosophy, Cika Ljubina 18-20, 11000 Belgrade, Serbia.

${ }^{3}$ Université de Nîmes, APSY-V, F-30021 Nîmes Cedex 1, France.

${ }^{3}$ Rio de Janeiro State University, Department of Psychology, Place Edmundo March 20, flat 201, Boa Viagem, Niterói, Rio de Janeiro, Brazil.

${ }^{3}$ The University of Sydney, School of Psychology, Manning Road, Camperdown, Sydney, Australia.

${ }^{3}$ Universidad San Martín de Porres, Psychology Research Institute, Av. Tomás Marsano 242, Lima 34, Peru.

${ }^{3}$ Pontificia Universidad Católica del Ecuador, Faculty of Psychology, Av. 12 de Octubre 1076 y Roca Quito,

Ecuador.

*University of Padua, Department of Women's and Children's Health, Via Giustiniani 3, 35128 Padua, Italy.

"Universidad Nacional de Educación a Distancia (UNED), Departamento de Psicología Social y de las

Organizaciones, Juan del Rosal, 10, 28040, Madrid, Spain.

${ }^{2}$ Alzahra University, Research Group of Psychology, Women Research Center, North Sheikh Bahaee St., Deh-e Vanak, 1993891176 Tehran, Iran.

"West University in Timisoara, Social Work Department, West University, Bul. Vasile Parvan nr.4, Timisoara, Romania.

"Université de Yaoundé 1, Department of Psychology, BP. 8056 Yaounde, Cameroon.

"Ulm University, Institute of Psychology and Education, Albert-Einstein-Allee 47, 89081 Ulm, Germany.

*Universidad Santo Tomás, Department of Psychology, Avenida Carlos Schorr 255, Talca, Región del Maule, Chile.

${ }^{4}$ Austral University of Chile, Institute of Psychology, Los Pinos Avenue, W/N, Pelluco, Puerto Montt, Chile. ${ }^{*}$ Konrad Lorenz University Foundation, Department of Psychology, Cra. 9 Bis \#62-43, 110231 Bogotá,

Colombia.

"Florida International University, Counseling, Recreation and School Psychology, 11200 SW 8 Str, Miami, Florida, USA. 
sUniversidad Nacional de Tucumán, Facultad de Medicina, Las Heras 429 7mo. B, Argentina. ${ }^{5}$ Institut Catholique de Toulouse, 31 rue de la Finderie, 7012, 31068 Toulouse Cedex 7, France.

sUniversité de Toulouse, Center for Studies and Research in Psychopathology and Health Psychology, UT2J, 5 All. Antonio Machado, 31058 Toulouse, France.

sUniversity of the Basque Country, Department of Personality, Evaluation and Psychological Treatments, Tolosa Hiribidea 70, Donostia 20018, Gipuzkoa, Basque Country, Spain.

${ }^{s}$ Aix Marseille Univ, PSYCLE, Aix en Provence, France.

sUniversity of Padova, Department of Developmental and Social Psychology, Via Venezia 8, 35141 Padova, Italy.

«University West, Department of Social and Behavioral Studies, 46186 Trollhättan, Sweden.

"University of Bucharest, Teacher Training Department, Panduri Street 90, Bucharest, Romania.

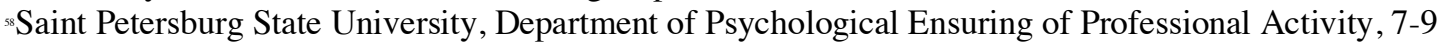

Universitetskaya Emb., St Petersburg, 199034, Russia.

${ }^{5}$ SWPS University of Social Sciences and Humanities, Faculty of Psychology in Sopot, Department of Psychology, 81-745 Sopot, ul. Polna 16/20, Poland.

${ }^{\star}$ Tilburg University, Departement Tranzo, Professor Cobbenhagenlaan 125, 5037 DB Tilburg, The Netherlands.

"Bahcesehir University, Department of Psychology, Guney Yerleskesi, Besiktas, Istanbul, Turkey.

"University of Habana, Faculty of Psychology, San Rafael \# 1168 e/. Mazón y Baserrate Plaza, Ciudad de La

Habana, Cuba.

"Chiang Mai University, Department of Psychology, 239 Suthep, Muang Chiang Mai, Chiang Mai 50200,

Thailand.

\section{Funding}

These studies were funded by a Special Research Fund granted to the first and last author (FSR2016) by UCLouvain.

\section{Conflict of Interest Statement}

M.M. and I.R. founded the Training Institute for Parental Burnout (TIPB) which delivers training on PB to professionals. The TIPB was founded after the completion of the study. The institute did not participate in the funding of this study, nor did it influence the process or the results in any way. 


\title{
Gender equality and maternal burnout: a 40-country study
}

\begin{abstract}
In Western countries, recent decades have witnessed a revolution towards gender equality. Inequalities have been greatly reduced in areas such as education or employment. Because inequalities lead to distress, this development has largely benefited women. One notable exception is the realm of parenting, which has remained rife with inequalities even in the most egalitarian countries. We hypothesized that experiencing inequality in parenting when one holds egalitarian values and raising a child in a country characterized by a high level of gender equality in other areas, increases mothers' psychological distress in the specific area of parenting. Multilevel modeling analyses computed among 11,538 mothers from 40 countries confirmed this prediction: high egalitarian values at the individual level and high gender equality at the societal level are associated with higher burnout levels in mothers. The associations hold beyond differences in sociodemographic characteristics at the individual level and beyond economic disparities at the societal level. These findings show the importance of egalitarian values and gender equality and their paradoxical effect when inequalities are still present in specific areas as parenting. This study reveals the crucial need to act not only at the micro level but also at the macro level to promote gender equality in parenting and prevent parental burnout.

Keywords: egalitarian values, gender equality paradox, culture, parental burnout, family policies
\end{abstract}

\section{Public Significance Statements}

This study shows that mothers suffer more from parental burnout when they experience inequality but hold egalitarian values and raise their children in a country 
Running head: GENDER EQUALITY AND PARENTAL BURNOUT

characterized by a high level of gender equality. The results suggest that gender equality backfires on mothers when equality is achieved in many areas such as education, employment, health and political empowerment, while inequality still prevails in parenthood. The results point to the need to implement social policies to achieve the same degree of gender equality in parenthood as in other areas. 
The 1960s marked the beginning of a revolution towards more egalitarian conditions in Western countries (Inglehart \& Norris, 2003). Women have joined men in the labor market, are entering male professions, and are increasingly being elected to political office (Cotter et al., 2008). By 1979, more than 150 United Nations member states had adopted laws for gender equality in political and public life, and in the specific fields of education, health and work (Committee on the Elimination of All Forms of Discrimination against Women, 1979). These societal changes parallel changes in individual mentalities towards more egalitarian values, i.e., beliefs that men and women should attain a certain degree of equality within both public and private realms of society (McDaniel, 2008). Women now want a career, and men want to play an active role as fathers (Amato et al., 2003). This progress towards gender equality is beneficial because social inequalities (e.g., income inequalities) have detrimental consequences on health and cause psychological distress (Wilkinson \& Pickett, 2006).

While there is no doubt that progress has been made towards gender equality in public areas such as education, employment, and even sport (England et al., 2020; Katsarova, 2019), gender equality may not have spread to the private sphere to the same extent (Hopcroft \& McLaughlin, 2012). And there is still one area of particular inequality: parenting (Renk et al., 2003). Even in countries that have achieved higher levels of gender equality regarding women's and men's economic participation, educational attainment, health and political empowerment, women still have the majority of duties related to childcare and education (Bianchi et al., 2012; Coltrane, 2000; Fleischmann \& de Haas, 2016; Hagqvist et al., 2017; Musick et al., 2016; Ory, 2016). These inequalities are reinforced by family policies that continue to designate mothers as the main caregiver, with for example, longer paid parental leave for mothers than for fathers (Ray et al., 2010).

On the grounds of previous evidence that parental burnout is more prevalent in countries scoring high on cultural individualism (Roskam et al., 2021), and that having more 
children was associated with higher depression for women, but not for men, in high gender equality countries (Hopcroft \& McLaughlin, 2012), we formulated the following hypothesis. Experiencing inequality in parenting when one holds egalitarian values or raising a child in a country characterized by a high level of gender equality in most areas except parenting, increases mothers' psychological distress in the parental role. What is the rationale for this assumption? Here, we put forward three explanations which are not mutually exclusive: unfulfilled expectations, social comparison processes across cultures, and the cost-value ratio of the child, to support our claim.

First, in countries where gender equality in the labor market is most supported by policies and laws, expectations that women and men will share equally in the tasks associated with family life are higher than in countries where work and family are perceived to be associated with more gender-specific roles (Hagqvist et al., 2017). But despite achievements in gender equality in work, women in these egalitarian countries are still expected to take responsibility for the home and children. And the norm of good motherhood still includes being the primary caregiver for children (Hagqvist et al., 2017; Hays, 1996). Women who experience inequality in parenting but hold egalitarian values or raise a child in a country characterized by a high level of gender equality in most areas except parenting, therefore experience a gap between their economic participation, educational attainment and personal opportunities, where they feel increasingly similar to their male counterparts, and the specific area of parenthood, where inequality is the rule rather than the exception. Such a gap contributes to unfulfilled expectations in mothers, a notion conceptualized as a chronic stressor by Wheaton (1999) and defined as ongoing frustration with structural constraints and a feeling of social role captivity as the goal (i.e. gender quality in the parental role) remains unreachable. A large longitudinal study in the US showed that unfulfilled expectations in areas such as education, employment, or parenthood are risk factors for depression even after 
Running head: GENDER EQUALITY AND PARENTAL BURNOUT

controlling for sociodemographic characteristics, family background, and prior mental health indicators (Mossakowski, 2011).

A second complementary avenue to explain why experiencing inequality in parenting when one holds egalitarian values or raising a child in a country characterized by a high level of gender equality in most areas except parenting may paradoxically increase mothers' psychological distress in the parental role, is based on social comparison processes across cultures. In particular, cultures differ in their use of gender-related social comparisons (Yuki, 2003). While between-gender social comparisons are mostly used in Western societies (i.e. those scoring high on gender equality), within-gender comparisons more frequently occur in non-Western societies (i.e. those scoring low on gender equality) (Guimond et al., 2007). As a result, mothers belonging to more egalitarian societies are more likely to compare themselves to fathers, and therefore suffer more from gender inequality in parenting than mothers from less egalitarian societies, who by contrast compare themselves more readily to other mothers, and will therefore be less at risk of parental burnout.

The value of the child in traditional versus developed societies is a third possible explanation for our hypothesis. The value attached to children has evolved throughout history and also differs from one culture to another. This value can be economic (e.g., children provide security for parents in old age), psychological (e.g., children are companions for their parents and a source of affection), or social (e.g., having children gives an identity and valuable social roles) (Kagitcibasi \& Ataca, 2005). While in traditional societies, the economic, psychological, and social value associated with children are still important, it has decreased in developed societies - a phenomenon that has been related to declining fertility (Caldwell, 1982; Kagitçibasi, 2007; Kagitcibasi \& Ataca, 2005). 
It could even be argued that children are a burden for some parents in developed Western societies (Hopcroft \& McLaughlin, 2012). According to some scholars, Western countries have entered the era of what Hays called "intensive parenting", a child-centered, expert-guided, emotionally absorbing, labor-intensive, and financially expensive approach to parenting (Hays, 1996). In countries where parenting is subject to high norms and standards and multiple recommendations about food, sleep, play, communication, and so on, children can be a real source of economic stress, because providing them with quality food, enrolling them in the best schools, and offering them stimulating and varied extracurricular activities are all expensive.

Beyond the economic cost, intensive parenting also has a psychological cost. It is for example strongly recommended that parents control their emotions in the presence of the child. They are strongly encouraged to display positive emotions such as showing pride to the child, but also to control negative emotions such as anger. The control of emotions by the parent has been shown to have very positive effects on child development (e.g. Chen et al., 2019), but it has a significant psychological cost for the parent (Karnilowicz et al., 2019; Le \& Impett, 2016). This cost linked to emotional labor is well known in organizational psychology (e.g., Grandey et al., 2013) and has also been highlighted recently in the field of parenthood by Lin et al. (2021). Parents are conscious of emotional display rules and therefore attempt to control their emotions, and these efforts are in turn associated with a risk of parental burnout.

Lastly, the social value of the child can also be diminished for women holding egalitarian values, and in countries characterized by a high level of gender equality. In a society where women have more similar opportunities as men for education, professional positions, and leisure activities, being a mother is less necessary to have a social identity. The parental identity is one possible identity among others. And it can even become a burden if 
Running head: GENDER EQUALITY AND PARENTAL BURNOUT

balancing different identities, for example professional and parental identities, proves difficult and stressful (Hopcroft \& McLaughlin, 2012).

In order to test our main hypothesis, the ranking of 40 countries on gender equality was obtained. In these 40 countries, data were collected from 11,538 mothers to assess their egalitarian values and one particular form of psychological distress related to parenting: parental burnout, a condition characterized by a feeling of exhaustion in parenting, an emotional distancing from one's children, a loss of pleasure and efficacy in one's parental role, and a contrast between previous and current parental self (Mikolajczak et al., 2019; Roskam et al., 2021). The aim of this study was to test the relation with parental burnout of mothers' egalitarian values and countries' level of gender equality.

\section{Method}

\section{Participants}

A sample of 11,538 mothers $\left(M_{a s e}=38.09, S D_{a g e}=8.08\right.$, range: $\left.18-88\right)$ from 40 countries was drawn from a larger database (including both genders) collected by the International Investigation of Parental Burnout (IIPB) Consortium between December 2017 and December 2019 (see Procedure below). Mothers were eligible to participate if they met the inclusion criterion of still having at least one child living at home. The sociodemographic characteristics of the pooled sample and of the sample in each country (sample size, age, educational level, working status, family types, number of children in the household, age of youngest child, age of oldest child, number of women and men living in household and caring for the children every day, years spent in the country, hours spent with children every day, and neighborhood profiles) are detailed in Table 1.

\section{Insert Table 1 about here}

\section{Procedure}


The data were collected through the International Investigation of Parental Burnout (IIPB) Consortium. The IIPB Consortium was set up by the first and last authors of the current study in 2017. They aimed to include in the consortium the widest possible range of countries in terms of geographical location, cultural values and socio-economic level. The countries involved in the IIPB used a common protocol which was translated using translation/back-translation procedures led by the consortium members and coordinated by the first author (for more information about the IIPB Consortium, see Roskam et al., 2021). The study was approved by the Institutional Review Board both at UCLouvain and in each country. Ethics approvals in each country are presented in Table S1.

Data were collected from January 2018 to March 2020. To avoid (self-)selection bias, mothers were not aware that the study focused on parental burnout. The survey was presented as a study designed to improve understanding of parental satisfaction and exhaustion around the world. After giving their informed consent, participants were invited to complete the questionnaire anonymously, but had the option of discontinuing their participation at any stage without justifying their withdrawal. The presentation of the survey (i.e., paper and pencil, or online) and the data collection procedure (newspaper advertisement, word of mouth, social networks, door-to-door, etc.) varied from country to country according to local practices. For a summary of the data collection procedure in each country, see Table S2.

\section{Measures}

In addition to demographic measures, the common IIPB protocol included several measures addressing different research questions and goals (e.g., comparing the prevalence of parental burnout across countries; investigating the relations between parental burnout and perceived/ideal parental self-discrepancies; examining the contribution of different parental duties to parental burnout). Because these questions are too different to be addressed in the same article, only the measures used in the current paper are described below. 


\section{Individual Level}

Sociodemographic characteristics. Participants were first asked about: their age; their educational level [number of successfully completed school years from the age of 6]; working status [in paid work or not]; family types [two-parent family; single parent family, step-family; others (e.g. polygamous family, two same-sex parents, multigenerational family)]; the number of children living in the household; the age of the youngest and the oldest child; the number of women (e.g. co-wife, grandmother, nanny, helper, etc.) living in the household/direct entourage and caring for the children on a daily basis (including the participant herself); the number of men (e.g. grandfather, uncle, etc.) living in the household/direct entourage and caring for the children on a daily basis; the number of hours they spent with the children per day (excluding nighttime hours), and neighborhood profile [disadvantaged; average; prosperous].

Parental burnout. Parental burnout was assessed with the Parental Burnout Assessment (PBA, Roskam et al., 2018), a 23-item questionnaire assessing the four core symptoms of parental burnout: emotional exhaustion (9 items) (e.g., I feel completely run down by my role as a parent), contrast with previous parental self (6 items) (e.g., I tell myself I'm no longer the parent I used to be), loss of pleasure in one's parental role (5 items) (e.g., I don't enjoy being with my children) and emotional distancing from one's children (3 items) (e.g., I am no longer able to show my children that I love them) using a 7-point frequency scale (never, a few times a year, once a month or less, a few times a month, once a week, a few times a week, every day).

Egalitarian values. Egalitarian values toward gender roles at the individual level were measured by four androgynist items selected by Constantin and Voicu (2015) from two largescale surveys used in cross-cultural research: the International Social Survey Programme (ISSP) 2002 and the World Values Survey (WVS) 2005. The items (i.e., Men ought to do a 
Running head: GENDER EQUALITY AND PARENTAL BURNOUT

larger share of childcare than they do now; Having a job is the best for a woman to be an independent person; Both the man and woman should contribute to the household income; Men ought to do a larger share of household work than they do now) were scored using a 7point frequency scale ranging from strongly disagree to strongly agree.

\section{Societal Level}

Gender equality. Gender equality was measured by referring to The Global Gender Gap Report 2018 (World Economic Forum, 2018) which scores 144 countries from zero (imparity) to one (parity) according to their gender equality situation on four dimensions: economic participation and opportunity, educational attainment, health and survival, and political empowerment. This index thus captures gender equality in all the most important areas, except for parenting, and is therefore unbiased by inequalities in parenting. For the 40 countries involved in the current study, gender equality ranged from .546 (Pakistan) to .823 (Finland). Gender equality indices in each country can be found in Table 2 for the 40 countries.

Gross Domestic Product per capita. The Gross Domestic Product per capita (GDP per capita) (current US\$) was measured as the Gross Domestic Product (GDP) divided by midyear population. GDP is the sum of gross value added by all resident producers in the economy plus any product taxes and minus any subsidies not included in the value of the products (The World Bank, 2018). For the 40 countries, values ranged from 271.75 (Burundi) to $86,429.5$ (Switzerland). They are displayed in Table 2 for the 40 countries.

\section{Insert Table 2 about here}

\section{Statistical Analyses}

Using the IIPB database containing data from 42 countries worldwide $(\mathrm{N}=17,409$, Roskam et al., 2021), participants meeting the inclusion criteria were selected for the present study: (i) mothers with at least one child still living in the family home (ii) who had 
completed the measures of interest, namely the sociodemographic variables, the parental burnout questionnaire, and the egalitarian values questionnaire (iii) from countries for which the variables at the societal level could be retrieved $\left(n_{\text {moners }}=11,538 ; n_{\text {counries }}=40\right)$.

The measurement invariance of the PBA had been tested and demonstrated in the IIPB seminal paper (Roskam et al., 2021) and this analysis was therefore not repeated here. However, the validity of the model of interest, i.e. 23 observed variables, 4 first-order factors, (Emotional Exhaustion, Emotional Distancing, Feelings of Being Fed Up, and Contrast), and one second-order factor (Parental Burnout), was tested in our sample. A confirmatory factorial analysis (CFA) was computed using maximum likelihood (ML) estimation and the Satorra-Bentler correction, i.e. Stata option vce(sbentler) (Satorra \& Bentler, 1991; Satorra \& Bentler, 1994) in Stata (StataCorp, 2019) to account for deviations from normality (Kline, 2015). The validity of the scale measuring egalitarian values (Constantin \& Voicu, 2015) was then tested on the pooled sample. A CFA using ML as the method of estimation and the vce(sbentler) Stata option was run. The model of interest contained four observed variables and one latent variable, i.e. Egalitarian Values. The measurement invariance was tested across the 21 languages. As with PBA in Roskam et al. (2021), this strategy was chosen so as not to exclude from the research countries with small sample sizes in which it was not possible to test the model. We wanted to avoid the risk of excluding countries in which data collection is more demanding and which are by definition less represented in the scientific literature. Gathering the subsamples according to the versions of the questionnaire, i.e. by language, allowed us to include a large number of countries in the analysis and research. First, the model of interest was estimated in each language separately. Second, configural invariance, implying the same pattern of latent constructs and observed items, with all parameters allowed to vary across groups, was tested. Next, metric equivalence where the factor loadings were constrained to be equal across groups was tested. This level of invariance corresponded 
to the minimum level to be reached in this study, in which the main multilevel analysis was interested in the regression coefficients between variables and not in the comparisons of the average levels of these variables between groups, which would require scalar invariance.

Several goodness-of-fit indices were used to determine the acceptability of the models: chisquare statistics, the root mean square error of approximation (RMSEA), the standardized root mean square residual (SRMR), the comparative fit index (CFI), and the Tucker-Lewis index (TLI). For CFI and TLI, values close to 0.90 or greater are acceptable to good. RMSEA and SRMR should preferably be less than or equal to 0.08 (Hu \& Bentler, 1999). For measurement invariance across a large number of groups $(>20)$, change in $\chi 2$ was reported and a criterion of a change in CFI of -.02 , paired with a change in RMSEA of .02 , was used (Cheung \& Rensvold, 2002; Rutkowski \& Svetina, 2014).

Regarding the main analyses, the bivariate associations between egalitarian values and parental burnout at the individual level, and between gender equality and parental burnout at the societal level, were first examined, as well as the cross-level bivariate correlation between egalitarian values and gender equality. At both levels, we checked for the presence of outliers. For the second main analysis, the multilevel random coefficient modeling analysis in Stata 16 was used to take the nested structure of the data into account. This analysis examined whether egalitarian values and gender equality continued to be related to mothers' parental burnout over and above their sociodemographic characteristics.

Next, the unconditional model was run. The individual- and societal-level variables were then entered in three steps. Conditional Model 1 controlled for sociodemographic variables. The egalitarian values measured at the individual level were entered in Conditional Model 2. Conditional Model 3 controlled for economic inequalities across countries. Gender equality obtained at the societal level as well as the interaction term between egalitarian values and gender equality were entered in Conditional Model 3. 
For the readability of the multilevel modeling results, the estimates of the standard deviation between $(\sqrt{\psi})$ and within countries $(\sqrt{\sqrt{\theta}})$ were translated into $\mathrm{R}^{2}$ as the percentage of variance explained by the covariates considered in each of the three conditional models. Following the recommendation of Raudenbush and Bryk (2002), the proportional reduction in each of the variance components was considered separately. $R_{2}^{2}$, referring to the percentage of explained variance between countries, was computed with the formula $\frac{R_{2}^{2}}{\Psi_{0}-\Psi_{1}} \psi_{0}$, where $\overline{\Psi_{0}}$ is the between-countries variance estimated under the unconditional model and $\overline{\Psi_{1}}$ is the between-countries variance estimated under the model of interest (i.e. Conditional Models 1 to 3 ). $R_{1}^{2}$, referring to the percentage of explained variance within countries, was computed with the formula $R_{1}^{2}=\frac{\theta_{0}-\theta_{1}}{\theta_{0}}$ where $\theta_{0}$ is the within-countries variance estimated under the unconditional model and $\theta_{1}$ is the within-countries variance estimated under the model of interest (i.e. Conditional Models 1 to 3).

All syntax is available at https://osf.io/g5k7q/?view only=bea4a7854a314b399cbfbb483237f75d .

\section{Results}

\section{Preliminary Analyses}

The CFA performed on the PBA in the pooled sample $(\mathrm{N}=11,538)$ displayed a good fit to the data, SB- $\chi^{2}(223)=7978.94, p<.001$, CFI_SB $=.93$, TLI $=92$, RMSEA_SB $=.055$, SRMR $=.042$. The standardized factor loadings ranged from .66 to .84 . The model of the egalitarian values in the pooled sample could not be estimated in the pooled sample $(\mathrm{N}=$ 11,538). The computation of the model in each language group showed that the model did not converge for the Basque version. The Basque group $(n=121)$ was removed and the CFAs were run successfully. The sample of 11,417 mothers was considered for the subsequent analyses. The CFA performed on the egalitarian values questionnaire in the pooled sample 
displayed a good fit to the data, SB- $\chi^{2}(1)=2.97, p=.085$, CFI_SB $=1.00, \mathrm{TLI}=.99$, RMSEA_SB $=.013$, SRMR $=.002$. The standardized factor loadings ranged from .46 to .63 . The model fit indices for the models of the egalitarian values in each language are displayed in Table S3. They demonstrated a very good fit to the data except for the Urdu version, for which the CFI and the SRMR were good whereas the TLI and the RMSEA were outside the acceptable parameters. Again with a view to including as many subsamples as possible in the study, and given that two fit indices were good, the data collected with the Urdu version were kept in the further analyses.

With regard to measurement invariance across languages, the model fit indices for the configural model were good $\chi^{2}(20)=32.23, p=.041, \mathrm{CFI}=.99, \mathrm{TLI}=.99, \mathrm{RMSEA}=.03$, $\mathrm{SRMR}=.01$. The model fit indices for the metric model were also good, $\chi^{2}(77)=177.06, p<$ $.001, \mathrm{CFI}=.99, \mathrm{TLI}=99, \mathrm{RMSEA}=.05, \mathrm{SRMR}=.06$, and the expected metric invariance was reached, $\Delta \mathrm{S}-\mathrm{B} \chi^{2}(57)=144.83, \Delta \mathrm{RMSEA}=.016, \Delta \mathrm{CFI}=.008$. The model fit indices for the scalar model were outside the acceptable parameters, $\chi^{2}(153)=2652.91, p<.001, \mathrm{CFI}=$ $.79, \mathrm{TLI}=84, \mathrm{RMSEA}=.17 \mathrm{SRMR}=.34$. However, as indicated above, this level of invariance was not needed for the questions/analyses of interest in this paper.

\section{Main Analyses}

Spearman's rank correlation between the study variables at the individual level are presented in Table 3. At the individual level, correlation analyses indicated a significant positive association between egalitarian values and parental burnout in the pooled sampled ( $r$ $=.17, \mathrm{p}<.001)$. The partial correlations between egalitarian values and parental burnout at the individual level accounting for sociodemographic characteristics for each country are displayed in Table 4. As shown, the pattern of correlations is not homogeneous. Positive low to moderate associations ranging from .10 to .33 were observed in most of the countries $(n=$ 27). However, we found very low associations (<.10) for 5 other countries, i.e., Burundi, 
China, Spain, Turkey, and Vietnam. Seven other countries displayed correlations close to zero, i.e. Algeria, Argentina, Cuba, Iran, Peru, Thailand, and Uruguay. Pakistan was identified as an outlier with $r=-.27$, and was therefore excluded from the multilevel analyses.

\section{Insert Tables 3 and 4 about here}

At the societal level, we found a significant association between gender equality and parental burnout $(r=.34, \mathrm{p}<.001)$. The mean level of parental burnout in each country is shown in Table 2. The associations between parental burnout and both egalitarian values and gender equality, were plotted for illustration purposes. As shown in Figure 1 (a), mothers with higher egalitarian values displayed a higher level of parental burnout than mothers with lower individual egalitarian values. As shown in Figure 1 (b), the country mean level of mothers' parental burnout was higher in countries displaying higher gender equality.

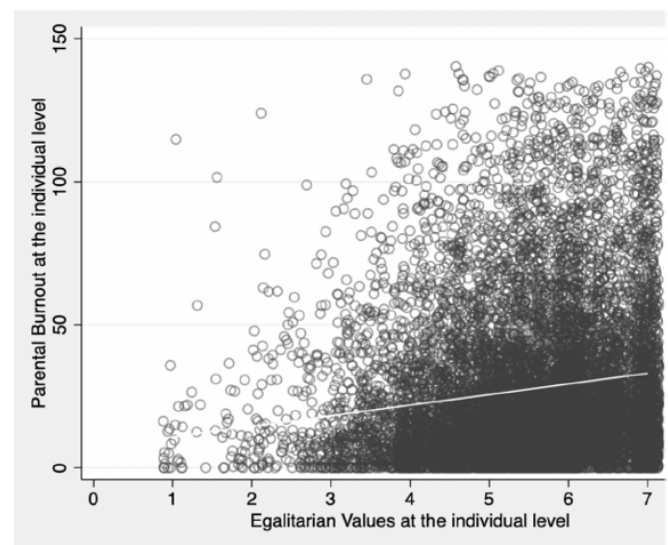

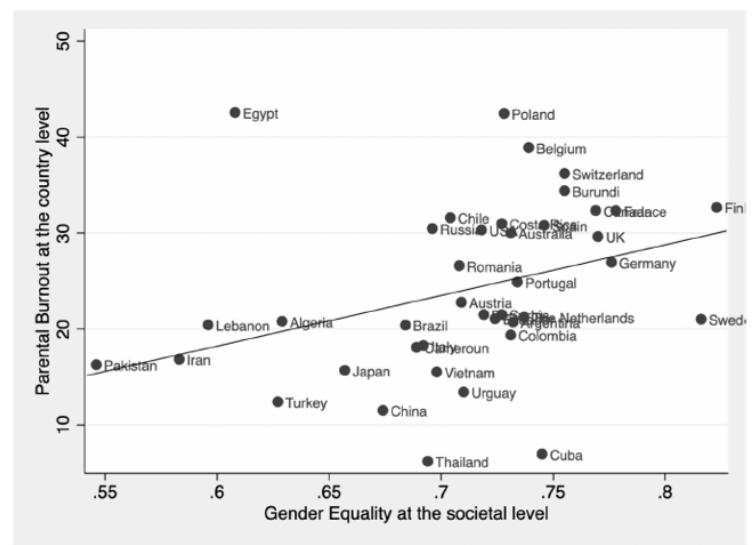

b

Fig. 1. Scatter plots of the bivariate association between egalitarian values and parental burnout at the individual level (a) and gender equality and parental burnout at the country level (b).

The examination of the graph at the societal level suggests the presence of outliers. In order to identify them, we estimated the standardized residuals. Four countries, i.e. Egypt, Cuba, Poland, Thailand, had residuals $>2$ and were therefore excluded from the multilevel analyses. 
Finally, the cross-level bivariate correlation between egalitarian values and gender equality was also found to be significant $(r=.11 \mathrm{p}<.001)$.

\section{Multilevel Analyses}

We first explored how much parental burnout varied at Level 1 (within countries, i.e., between mothers) and at Level 2 (between countries). The mean level of parental burnout estimated in 10,502 mothers nested in 35 countries was 27.50 , and varied more within countries (i.e., between mothers), $s d=25.96$, than between countries, $s d=7.23$. The findings of the multilevel random coefficient model (Table 5) showed that both egalitarian values at the individual level and gender equality at the societal level were significantly predictive of parental burnout beyond sociodemographic variables at the individual level, and beyond economic inequalities across countries at the societal level. In terms of sociodemographic predictors, a significant effect of working status was found: being in paid work was a protective factor with regard to parental burnout. Also, the number of children was positively related to the level of parental burnout. Parents having children at younger age displayed a significantly higher level of parental burnout. The number of men involved in childcare was a protective factor against mothers' burnout, as was living in a more prosperous neighborhood. The sociodemographic variables accounted for $2.06 \%$ of the variance within countries, which is in line with previous results of independent studies using large samples of participants originating from different cultures around the globe (e.g. Arikan et al., 2020; Gannagé et al., 2020; Matias et al., 2020; Mikolajczak et al., 2018; Mousavi et al., 2020; Stănculescu et al., 2020; Szczygieł et al., 2020). All of these report that sociodemographic characteristics account for a small proportion of explained variance in interindividual differences in parental burnout. However, since the sociodemographic characteristics vary not only within countries but also between countries, our main analysis showed that the sociodemographic variables accounted for $10.86 \%$ of the variance in parental burnout between countries. 
Over and above these sociodemographic predictors, a significant effect of mothers' egalitarian values was found. The higher their egalitarian values, the higher their level of parental burnout. While taking this predictor into account only explains $3.96 \%$ of the variability between mothers within countries (including the variance explained by the covariates), the addition of this predictor in the second model increased the percentage of variance explained to $14.88 \%$ of the differences between countries. In the third model, the introduction of the two variables measured at the country level (i.e. GDP per capita and gender equality) and the cross-level interaction between egalitarian values and gender equality further increased the percentage of variance explained between countries, bringing it to $50.31 \%$. The effect of our variable of interest, i.e. gender equality, was significant after controlling for economic inequalities between countries. The cross-level interaction shows that higher egalitarian values at the individual level increases the risk of parental burnout slightly more for mothers raising their children in a country characterized by a higher level of gender equality.

\section{Insert Table 5 about here}

\section{Discussion}

The aim of this research was to investigate the impact of mothers' egalitarian values and societal level of gender equality as risk factors for parental burnout across 40 countries. The hypothesis we posed may seem counter-intuitive at first sight. It did not seem logical that mothers who are a priori the least confined in their (traditional) role as mothers and who raise their children in societies where they are considered the most equal to fathers, are in fact the most at risk of suffering from parental burnout. However, the result, namely that higher levels of maternal burnout are associated to higher egalitarian values and found in more egalitarian countries, was not unexpected. It is consistent with previous evidence that parental burnout is more prevalent in Western culture and that having more children is associated with higher 
depression for women in countries characterized by a high level of gender equality (Hopcroft \& McLaughlin, 2012; Roskam et al., 2021). Based on the current study, we cannot rule out the possibility that the higher level of maternal burnout in more egalitarian countries may be part of a larger pattern of findings showing a tendency to report more symptoms and negative states in more egalitarian countries and in more individualistic cultures ( $\mathrm{Li}$ et al., 2021; Roskam et al., 2021). This tendency could be driven by lower levels of stigma and moralization associated with mental health issues, in particular depression, in Western countries (Krendl \& Pescosolido, 2020).

The current results suggest that the issue of gender equality may be a specific risk factor for parental burnout in mothers. However, identifying the process at work in the relationship between gender equality and maternal burnout is particularly challenging. Gender equality is a very broad phenomenon that cannot be summarized in a single indicator such as the Global Gender Gap index (World Economic Forum, 2018). Given the difficulty of collecting comparable information across countries on gender equality in the economic, political, educational, sport, and parental areas, this type of indicator provides the opportunity to conduct studies on a large number of countries and compare them with each other, but a comparison based on this indicator alone is de facto limited. Nor does it allow us to understand the mechanisms at play in the relationships observed. Understanding these mechanisms is a matter for the researcher's interpretation, based on relevant concepts and theories.

Here, we used several complementary theoretical arguments regarding the specific effect of egalitarian values and gender equality on maternal burnout to provide solid grounding for the study hypothesis. These arguments included unfulfilled expectations, social comparison processes across culture, and change in the cost-value ratio of the child.

Consistently with our theoretically-based assumption, the results mainly confirmed that 
experiencing inequality when one holds egalitarian values and raising a child in a country characterized by a high level of gender equality in most areas except parenting, contribute to parental burnout in mothers. Moreover, the results revealed an interaction effect between egalitarian values at the individual level and gender equality at the societal level. This crosslevel interaction suggests that in countries characterized by a high level of gender equality, holding egalitarian values correlate slightly more strongly with parental burnout.

The theoretical arguments on which we have relied seem convincing, and we believe that unfulfilled expectations, social comparison processes across culture, and the cost-value ratio of the child, are good candidates as mediators between both gender equality and egalitarian values on the one hand, and parental burnout on the other. Although none of these potential mediators were measured in the present study, they are interesting topics for future research.

The conclusion that experiencing inequality when one holds egalitarian values and raising a child in a country countries characterized by a high level of gender equality are risk factors for maternal burnout, cannot be considered universal. Indeed, we have identified, among the 40 countries participating in this research, one outlier at the within-country level and four outliers at the between-country level. We also identified correlation coefficients close to zero between egalitarian values and parental burnout in seven countries. This suggests that having more egalitarian values as a mother is not a risk factor in all cultures and that raising children in a country characterized by a high level of gender equality is not systematically a risk factor for maternal burnout.

In particular, Egypt was the most significant outlier in the societal level analyses. Mothers reported a very high level of parental burnout while raising their children in a country with low gender equality. This result reflects the particular situation in this country, 
which is characterized by a large increase in the percentage of women in the labor force. According to official statistics (Central Agency for Public Mobilization and Statistics, 2021), a high percentage (16\%) of Egyptian women are breadwinners. Among them are many widows and divorcees. The pressure to work is high and women are under even more pressure because they have to balance work-related responsibilities with those of caring for and raising children, which almost exclusively rely on women even when they raise their children in a two-parent family. In addition, the gender inequality that prevails in this society, especially in economic participation and political empowerment, means that women's professional role is severely limited. They are restricted in the kind of work they can do. They are also subject to discrimination when it comes to promotions or the choice of higher positions, for example.

Poland is another country with a significantly higher level of parental burnout than other countries with the same level of gender equality. In line with previous evidence that the social context, in particular the public policies designed to reduce the burden of having children, plays an essential role in predicting parental well-being (e.g., Pollmann-Schult, 2018; Stier \& Kaplan, 2020), Szczygieł et al. (2020) suggested that the low formal support offered to Polish parents explains the high level of parental burnout. A very telling example is that Poland stands out from many other European countries as regards the availability of early childhood education and care (ECEC). In 2017, only $11.6 \%$ of children under the age of 3 benefited from ECEC, while the average percentage was $34.2 \%$ across European countries (Commission/EACEA/Eurydice., 2019). As mothers are still the primary caregivers in Poland (Plomien, 2009), they are likely to be particularly affected by the lack of formal support. In addition, the rapid growth of individualistic values in Poland (Brycz et al., 2015) has led to a decrease in the informal support that mothers of previous generations could rely on in a more collectivist society. For example, there has been a decline in the number of grandparents involved in caring for their grandchildren in Poland in recent years (Kotowska et al., 2016). 
Cuba contrasts very strongly with Poland in our results at the societal level: the level of parental burnout is extremely low, while the level of gender equality is comparable to that of Poland. In contrast to Poland, the formal and informal social support that mothers receive in Cuba is very high. On the formal side, the country provides parents with free ECEC and cultural and sports activities for their children. All Cuban mothers, regardless of their social or economic status, can therefore offer their children a good education and opportunities for development through the services and facilities available to them. Maternity leave is also offered to mothers for one year, but women have the choice to shorten it if they wish to return to work. On the informal side, parents can rely on the help of grandparents and members of the community or neighborhood. The role of the mother is highly respected in Cuban society, which recognizes that mothers play an essential role in the development of the child. Mothers have a very special place in this society. They are venerated in such a way that children have a great social and psychological value (Caram León, 2005; Díaz Cuellar et al., 2017).

As for Thailand, its position on the regression line shown in Figure $1 \mathrm{~b}$ might suggest that the situation there is comparable to that of Cuba. The two countries do indeed common points, but there are also important differences. Of the 40 countries that participated in the study, these two countries have the highest rate of intergenerational families, at over $25 \%$ (see the "other" category in Table 1). And according to Thai official statistics (UNFPA, 2015), the proportion of three-generation families increased to $33.6 \%$ whereas that of two-parent families decreased to $26.6 \%$ from 1987 to 2013 . Cuba and Thailand thus have in common the high rate of support that parents find in their family, which may explain the near-to-zero level of parental burnout in these two countries. However, Cuba and Thailand greatly differ on gender equality issues. Whereas Cuba can be considered a country where gender equality is progressing quite homogeneously, the lower (but average) level of gender equality displayed by Thailand may hide a heterogenous situation and represent a compromise between opposing 


\section{Running head: GENDER EQUALITY AND PARENTAL BURNOUT}

trends. Whereas gender equality can be considered as high in educational attainment, health and survival and to a slightly lesser extent, economic participation, inequality in political empowerment remains extremely prevalent (World Economic Forum, 2018). To illustrate this, there are currently only 76 female MPs in Thailand out of a total of 500, i.e. $14 \%$, only one female minister (the education minister), and only one female governor. This situation may be specific to Thailand compared to other Asian countries. The attitude towards gender equality is more homogeneous there: in China or Japan, for example, gender equality is, depending on the index used (World Economic Forum, 2018), weaker, and these values are progressing slowly but more consistently across domains. The Thai heterogeneity may explain why the indicator we used here is not a good predictor of the level of maternal burnout and why Thailand was found to be an outlier.

\section{Strengths and Limitations}

The strengths of this study are its topic of universal interest to a broad readership including psychologists, psychiatrists, historians, anthropologists, sociologists, health economists and policy makers, the large sample from 40 countries, the participation of countries not usually represented in the scientific literature, the complementary use of data from international databases independent of the data collected from the participants, and the fact that the nested model controls for differences in socio-demographic, economic and cultural background both at the individual and societal levels. Despite its interesting results, this study is not exempt from limitations. First, it cannot be asserted that the samples from which the data were collected in the different countries were fully representative of the populations. In most countries, the samples were convenient and snowball. As is often the case with questionnaire studies, the participants were relatively highly educated. In addition, the samples collected in the different countries are probably not equivalent in their nonrepresentativeness. The interpretation of the results must therefore take this limit on generality 
into account. Second, the study found that mothers suffer more from parental burnout when they hold egalitarian values and are raising their children in a country where gender equality is high in areas such as education, employment, health and political empowerment, yet inequality still prevails in parenthood. However, inequalities in parenting have not been effectively measured. In the absence of such a measure, the hypothesis and the interpretation of the findings were based on international surveys and empirical research showing a strong gender imbalance in duties related to childcare and parenting, even in egalitarian countries (Bianchi et al., 2012; Coltrane, 2000; Fleischmann \& de Haas, 2016; Musick et al., 2016; Ory, 2016). Third, the study would have benefited from the inclusion of a measure of task-sharing between mother and father, since if mothers suffer from parental burnout when they hold egalitarian values but inequalities prevail in parenting, this effect will be explained and/or amplified by low task-sharing with fathers.

\section{Conclusion}

Despite increasingly egalitarian ideologies and huge progress towards higher gender equality in areas such as education, employment, healthcare and political empowerment, parenting has remained a strongly gendered area. Burnout seems to be the price to pay for inequality in the specific area of parenting. Given the deleterious consequences of parental burnout for both parents and their children, our findings suggest that social changes are needed to boost gender equality in parenthood. The exhaustion of egalitarian mothers is regrettable, because in essence, gender equality is truly beneficial for both women and men. Social policies must be implemented to achieve higher degree of gender equality in parenthood as in other areas such as education, employment, health and political empowerment. If not, mothers' parental burnout lurks around the corner. 
Running head: GENDER EQUALITY AND PARENTAL BURNOUT

\section{Author Contributions}

I.R. and M. M. designed the study. I.R. coordinated the IIPB consortium, undertook data collection, and merged the data sets. L.G. collected the Belgian data, computed preliminary analyses, and drafted a preliminary version of the paper. I.R. computed the analyses and wrote the original draft of the paper. M.M. reviewed and edited the paper. All authors have approved the final version of the manuscript for submission.

\section{ORCID iDs}

I.R.: https://orcid.org/0000-0002-1449-1133

L.G.: https://orcid.org/0000-0003-1651-3129

M.M.: https://orcid.org/0000-0002-7333-1578

\section{Open Practices}

The study reported in this paper was not preregistered. The anonymized data, materials and the SPSS syntax are publicly available:

https://osf.io/g5k7q/?view_only=bea4a7854a314b399cbfbb483237f75d.

\section{Supplemental Material}

Additional information can be found online at XXX. 


\section{References}

Amato, P. R., Johnson, D. R., Booth, A., \& Rogers, S. J. (2003). Continuity and Change in Marital Quality Between 1980 and 2000. Journal of Marriage and Family, 65(1), 122. https://doi.org/https://doi.org/10.1111/j.1741-3737.2003.00001.x

Arikan, G., Üstündağ-Budak, A. M., Akgün, E., Mikolajczak, M., \& Roskam, I. (2020). Validation of the Turkish version of the Parental Burnout Assessment (PBA). New Directions for Child and Adolescent Development, 2020(174), 15-32. https://doi.org/https://doi.org/10.1002/cad.20375

Bianchi, S. M., Sayer, L. C., Milkie, M. A., \& Robinson, J. P. (2012). Housework: Who Did, Does or Will Do It, and How Much Does It Matter? Social forces; a scientific medium of social study and interpretation, 91(1), 55-63. https://doi.org/10.1093/sf/sos120

Brycz, H., Rózycka-Tran, J., \& Szczepanik, J. (2015). Cross-cultural differences in metacognitive self. Economics and Sociology, 8, 127-134. https://doi.org/10.14254/2071-789x.2015/8-1/12

Caldwell, J. C. (1982). Theory of fertility decline. London: Academic Press.

Caram León, T. (2005). Mujer y poder en Cuba. In F. Rojas Aravena (Ed.), La gobernabilidad en América Latina. Balance reciente y tendencias a futuro. Facultad Latinoamericana de Ciencias Sociales. http://bibliotecavirtual.clacso.org.ar/ar/libros/cuba/flacso/caram.pdf

Central Agency for Public Mobilization and Statistics, C. (2021). Egypt statistics. https://www.capmas.gov.eg/HomePage.aspx

Chen, Y., Haines, J., Charlton, B. M., \& VanderWeele, T. J. (2019). Positive parenting improves multiple aspects of health and well-being in young adulthood. Nature Human Behaviour, 3(7), 684-691. https://doi.org/10.1038/s41562-019-0602-x 
Running head: GENDER EQUALITY AND PARENTAL BURNOUT

Cheung, G. W., \& Rensvold, R. B. (2002). Evaluating Goodness-of-Fit Indexes for Testing Measurement Invariance. Structural Equation Modeling: A Multidisciplinary Journal, 9(2), 233-255. https://doi.org/10.1207/S15328007SEM0902_5

Coltrane, S. (2000). Research on Household Labor: Modeling and Measuring the Social Embeddedness of Routine Family Work. Journal of Marriage and Family, 62(4), 1208-1233. https://doi.org/https://doi.org/10.1111/j.1741-3737.2000.01208.x

Commission/EACEA/Eurydice., E. (2019). Key data on early childhood education and care in Europe (Eurydice Report). https://eacea.ec.europa.eu/nationalpolicies/eurydice/sites/eurydice/files/kd ecec 2019 report en.pdf

Committee on the Elimination of All Forms of Discrimination against Women, C. (1979). Convention on the Elimination of All Forms of Discrimination against Women New York, 18 December 1979. United Nations Human Rights. https://www.ohchr.org/en/professionalinterest/pages/cedaw.aspx

Constantin, A., \& Voicu, M. (2015). Attitudes towards gender roles in cross-cultural surveys: Content validity and cross-cultural measurement invariance. Social Indicators Research, 123(3), 733-751.

Cotter, D. A., Hermsen, J. M., \& England, P. (2008). Moms and jobs: Trends in mothers' employment and which mothers stay home. American families: A multicultural reader, 2, 379-386.

Díaz Cuellar, F. E., Castro Gutiérrez, E., Mestre Oviedo, J., González Landrián, L., Torres Cancino, I., \& Castro Alonso, M. (2017). La mujer cubana: evolución de derechos y barreras para asumir puestos de dirección. Revista Médica Electrónica, 39, 1180-1191. http://scielo.sld.cu/scielo.php?script=sci arttext\&pid=S1684$18242017000500019 \&$ nrm $=$ iso 
Running head: GENDER EQUALITY AND PARENTAL BURNOUT

England, P., Levine, A., \& Mishel, E. (2020). Progress toward gender equality in the United States has slowed or stalled. Proceedings of the National Academy of Sciences, 117(13), 6990-6997. https://doi.org/10.1073/pnas.1918891117

Fleischmann, F., \& de Haas, A. (2016). Explaining parents' school involvement: The role of ethnicity and gender in the Netherlands. The Journal of Educational Research, 109(5), 554-565. https://doi.org/10.1080/00220671.2014.994196

Gannagé, M., Besson, E., Harfouche, J., Roskam, I., \& Mikolajczak, M. (2020). Parental burnout in Lebanon: Validation psychometric properties of the Lebanese Arabic version of the Parental Burnout Assessment. New Directions for Child and Adolescent Development, 2020(174), 51-65. https://doi.org/https://doi.org/10.1002/cad.20383

Grandey, A. A., Diefendorff, J. M., \& Rupp, D. E. (2013). Emotional labor in the 21st century: Diverse perspectives on emotion regulation at work. New York, NY, US: Routledge/Taylor \& Francis Group.

Guimond, S., Branscombe, N. R., Brunot, S., Buunk, A. P., Chatard, A., Désert, M., Garcia, D. M., Haque, S., Martinot, D., \& Yzerbyt, V. (2007). Culture, gender, and the self: Variations and impact of social comparison processes. Journal of Personality and Social Psychology, 92(6), 1118-1134. https://doi.org/10.1037/0022-3514.92.6.1118

Hagqvist, E., Gådin, K. G., \& Nordenmark, M. (2017). Work-Family Conflict and WellBeing Across Europe: The Role of Gender Context. Social Indicators Research, 132(2), 785-797. https://doi.org/10.1007/s11205-016-1301-X

Hays, S. (1996). The Cultural Contradictions of Motherhood. New Haven: Yale University Press.

Hopcroft, R. L., \& McLaughlin, J. (2012). Why is the sex gap in feelings of depression wider in high gender equity countries? The effect of children on the psychological well- 
Running head: GENDER EQUALITY AND PARENTAL BURNOUT

being of men and women. Social Science Research, 41(3), 501-513.

https://doi.org/10.1016/j.ssresearch.2011.12.006

Hu, L., \& Bentler, P. M. (1999). Cutoff criteria for fit indexes in covariance structure analysis: Conventional criteria versus new alternatives. Structural Equation Modeling, 6, 1-55. https://doi.org/10.1080/10705519909540118

Kagitçibasi, C. (2007). Family, self, and human development across cultures. Theory and applications. Mahwah: Lawrence Erlbaum Associates.

Kagitcibasi, C., \& Ataca, B. (2005). Value of Children and Family Change: A Three-Decade Portrait From Turkey. Applied Psychology: An International Review, 54(3), 317-337. https://doi.org/10.1111/j.1464-0597.2005.00213.X

Karnilowicz, H. R., Waters, S. F., \& Mendes, W. B. (2019). Not in front of the kids: Effects of parental suppression on socialization behaviors during cooperative parent-child interactions. Emotion, 19(7), 1183-1191. https://doi.org/10.1037/emo0000527

Katsarova, I. (2019). Gender equality in sport: Getting closer every day. https://library.olympics.com/Default/doc/SYRACUSE/185927/gender-equality-insport-getting-closer-every-day-ivana-katsarova

Kline, R. B. (2015). Principles and practice of structural equation modeling (4th edition). New York: Guilford publications.

Kotowska, I. E., Matysiak, A., \& Mynarska, M. (2016). The life of Poles: From leaving the parental home to retirement. Insights from the generations and gender survey (GGS$P L)$. Warszawa: Institute of Statistics and Demography, Collegium of Economic Analysis, Warsaw School of Economics.

Krendl, A. C., \& Pescosolido, B. A. (2020). Countries and Cultural Differences in the Stigma of Mental Illness: The East-West Divide. Journal of Cross-Cultural Psychology, 51(2), 149-167. https://doi.org/10.1177/0022022119901297 
Running head: GENDER EQUALITY AND PARENTAL BURNOUT

Le, B. M., \& Impett, E. A. (2016). The Costs of Suppressing Negative Emotions and Amplifying Positive Emotions During Parental Caregiving. Personality and Social Psychology Bulletin, 42(3), 323-336. https://doi.org/10.1177/0146167216629122

Li, Z., Wei, A., Palanivel, V., \& Jackson, J. C. (2021). A Data-Driven Analysis of Sociocultural, Ecological, and Economic Correlates of Depression Across Nations. Journal of Cross-Cultural Psychology. https://doi.org/10.1177/00220221211040243

Lin, G.-X., Hansotte, L., Szczygieł, D., Meeussen, L., Roskam, I., \& Mikolajczak, M. (2021). Parenting with a smile: Display rules, regulatory effort, and parental burnout. Journal of Social and Personal Relationships, 38(9), 2701-2721. https://doi.org/10.1177/02654075211019124

Matias, M., Aguiar, J., César, F., Braz, A. C., Barham, E. J., Leme, V., Elias, L., Gaspar, M. F., Mikolajczak, M., Roskam, I., \& Fontaine, A. M. (2020). The Brazilian-Portuguese version of the Parental Burnout Assessment: Transcultural adaptation and initial validity evidence. New Directions for Child and Adolescent Development, 2020(174), 67-83. https://doi.org/https://doi.org/10.1002/cad.20374

McDaniel, A. E. (2008). Measuring Gender Egalitarianism: The Attitudinal Difference between Men and Women. International Journal of Sociology, 38(1), 58-80. http://www.jstor.org/stable/20628319

Mikolajczak, M., Gross, J. J., \& Roskam, I. (2019). Parental Burnout: What Is It, and Why Does It Matter? Clinical Psychological Science, 7(6), 1319-1329. https://doi.org/10.1177/2167702619858430

Mikolajczak, M., Raes, M.-E., Avalosse, H., \& Roskam, I. (2018). Exhausted parents: Sociodemographic, child-related, parent-related, parenting and family-functioning correlates of parental burnout. Journal of Child and Family Studies, 27(2), 602-614. https://doi.org/https://doi.org/10.1007/s10826-017-0892-4 
Running head: GENDER EQUALITY AND PARENTAL BURNOUT

Mossakowski, K. N. (2011). Unfulfilled expectations and symptoms of depression among young adults. Social Science and Medicine, 73(5), 729-736. https://doi.org/10.1016/j.socscimed.2011.06.021

Mousavi, S. F., Mikolajczak, M., \& Roskam, I. (2020). Parental burnout in Iran: Psychometric properties of the Persian (Farsi) version of the Parental Burnout Assessment (PBA). New Directions for Child and Adolescent Development, 2020(174), 85-100. https://doi.org/https://doi.org/10.1002/cad.20369

Musick, K., Meier, A., \& Flood, S. (2016). How Parents Fare:Mothers' and Fathers' Subjective Well-Being in Time with Children. American Sociological Review, 81(5), 1069-1095. https://doi.org/10.1177/0003122416663917

Ory, B. (2016). Bridging the gender gap at home?

https://demotrends.org/2016/05/03/bridging-the-gender-gap-at-home/

Plomien, A. (2009). Welfare State, Gender, and Reconciliation of Work and Family in Poland: Policy Developments and Practice in a New EU Member. Social Policy \& Administration, 43(2), 136-151. https://doi.org/https://doi.org/10.1111/j.14679515.2009.00652.x

Pollmann-Schult, M. (2018). Parenthood and Life Satisfaction in Europe: The Role of Family Policies and Working Time Flexibility. European Journal of Population, 34(3), 387411. https://doi.org/10.1007/s10680-017-9433-5

Raudenbush, S., \& Bryk, A. (2002). Hierarchical Linear Models: Applications and Data Analysis Methods (2nd ed.). Thousand Oaks, CA: Sage.

Ray, R., Gornick, J. C., \& Schmitt, J. (2010). Who cares? assessing generosity and gender equality in parental leave policy designs in 21 countries. Journal of European Social Policy, 20(3), 196-216. https://doi.org/10.1177/0958928710364434 
Renk, K., Roberts, R., Roddenberry, A., Luick, M., Hillhouse, S., Meehan, C., Oliveros, A., \& Phares, V. (2003). Mothers, Fathers, Gender Role, and Time Parents Spend with Their Children. Sex Roles, 48(7), 305-315.

https://doi.org/https://doi.org/10.1023/A:1022934412910

Roskam, I., Aguiar, J., Akgun, E., Arikan, G., Artavia, M., Avalosse, H., Aunola, K., Bader, M., Bahati, C., Barham, E. J., Besson, E., Beyers, W., Boujut, E., Brianda, M. E., Brytek-Matera, A., Carbonneau, N., César, F., Chen, B.-B., Dorard, G., dos Santos Elias, L. C., Dunsmuir, S., Egorova, N., Favez, N., Fontaine, A.-M., Foran, H., Fricke, J., Furutani, K., Gallée, L., Gannagé, M., Gaspar, M., Godbout, L., Goldenberg, A., Gross, J. J., Gurza, M. A., Hall, R., Hashmi, M. A., Hatta, O., Helmy, M., Hoang, T. V., Huynh, M. T., Kaneza, E., Kawamoto, T., Knezevic, G., Kpassagou, B. L., Lazarevic, L. B., Le Vigouroux, S., Lebert-Charron, A., Leme, V., Lin, G.-X., MacCann, C., Manrique-Millones, D., Matias, M., Miranda-Orrego, M. I., Miscioscia, M., Morgades-Bamba, C., Mousavi, S. F., Moutassem-Mimouni, B., Muntean, A., Murphy, H., Ndayizigiye, A., Tenkue, J. N., Olderbak, S., Ornawka, S., Osman, F., Oyarce-Cadiz, D., Pérez-Díaz, P. A., Petrides, K. V., Pineda-Marin, C., Prandstetter, K., Prikhidko, A., Ricci, R. T., Salinas-Quiroz, F., Sánchez-Rodríguez, R., Sarrionandia, A., Scola, C., Sezibera, V., Silva, P., Simonelli, A., Soenens, B., Sorbring, E., Sorkkila, M., Schrooyen, C., Stănculescu, E., Starchenkova, E., Szczygiel, D., Tapia, J., Tri, T. M. T., Tremblay, M., Ustundag-Budak, A. M., Pacheco, M. V., van Bakel, H., Verhofstadt, L., Wendland, J., Yotanyamaneewong, S., \& Mikolajczak, M. (2021). Parental Burnout Around the Globe: a 42-Country Study. Affective Science, 2(1), 58-79. https://doi.org/10.1007/s42761-020-00028-4

Roskam, I., Brianda, M. E., \& Mikolajczak, M. (2018). A Step Forward in the Conceptualization and Measurement of Parental Burnout: The Parental Burnout 
Running head: GENDER EQUALITY AND PARENTAL BURNOUT

Assessment (PBA). Frontiers in Psychology, 9(758).

https://doi.org/10.3389/fpsyg.2018.00758

Rutkowski, L., \& Svetina, D. (2014). Assessing the hypothesis of measurement invariance in the context of large-scale international surveys. Educational and Psychological Measurement, 74(1), 31-57. https://doi.org/10.1177/0013164413498257

Satorra, A., \& Bentler, P. (1991). Goodness-of-fit test under IV estimation: Asymptotic robustness of a NT test statistic. In R. Gutiérrez \& M. J. Valderrama (Eds.), Applied stochastic models and data analysis (pp. 555-567). World Scientific.

Satorra, A., \& Bentler, P. M. (1994). Corrections to test statistics and standard errors in covariance structure analysis. In A. von Eye \& C. C. Clogg (Eds.), Latent variables analysis: Applications for developmental research. (pp. 399-419). Sage Publications, Inc.

Stănculescu, E., Roskam, I., Mikolajczak, M., Muntean, A., \& Gurza, A. (2020). Parental burnout in Romania: Validity of the Romanian version of the parental burnout assessment (PBA-RO). New Directions for Child and Adolescent Development, 2020(174), 119-136. https://doi.org/https://doi.org/10.1002/cad.20384

StataCorp. (2019). Stata Statistical Software: Release 16. In StataCorp LLC.

Stier, H., \& Kaplan, A. (2020). Are Children a Joy or a Burden? Individual- and Macro-level Characteristics and the Perception of Children. European Journal of Population, 36(2), 387-413. https://doi.org/10.1007/s10680-019-09535-y

Szczygieł, D., Sekulowicz, M., Kwiatkowski, P., Roskam, I., \& Mikolajczak, M. (2020). Validation of the Polish version of the Parental Burnout Assessment (PBA). New Directions for Child and Adolescent Development, 2020(174), 137-158. https://doi.org/https://doi.org/10.1002/cad.20385 
Running head: GENDER EQUALITY AND PARENTAL BURNOUT

The World Bank, W. B. (2018). Gross Domestic Product per capita. Retrived online at https://data.worldbank.org/indicator/NY.GDP.PCAP.CD

UNFPA. (2015). State of Thailand population report 2015: Features of Thai families in the era of low fertility and longevity. . https://thailand.unfpa.org/sites/default/files/pubpdf/State\%20of\%20Thailand\%20Population\%20report\%202015Thai\%20Family en.pdf

Wheaton, B. (1999). Social stress. In C. S. Aneshensel \& J. C. Phelan (Eds.), Handbook of the sociology of mental health (pp. 277-300). Kluwer Academic/Plenum Publishers.

Wilkinson, R. G., \& Pickett, K. E. (2006). Income inequality and population health: a review and explanation of the evidence. Social Science and Medicine, 62(7), 1768-1784. https://doi.org/10.1016/j.socscimed.2005.08.036

World Economic Forum, W. E. F. (2018). The Global Gender Gap Report. Retrieved online at http://www3.weforum.org/docs/WEF GGGR 2018.pdf

Yuki, M. (2003). Intergroup comparison versus intragroup relationships: A cross-cultural examination of social identity theory in North American and East Asian cultural contexts. Social Psychology Quarterly, 66(2), 166-183.

https://doi.org/10.2307/1519846 
Table 1. Sociodemographic Characteristics: Sample Size and Mean Age, Educational Level, Working Status, Family Types, Number of Children in the Household, Age of the Youngest Child, Age of the Oldest Child, Number of Women Caring for Children, Number of Men Caring for Children, Hours Spent With Children per Day, Neighborhood Profiles (Standard Deviations are in Parentheses)

\begin{tabular}{|c|c|c|c|c|c|c|c|c|c|c|c|c|c|c|c|c|c|}
\hline & \multirow[b]{2}{*}{ 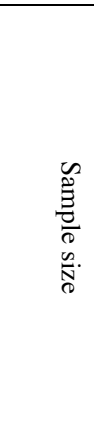 } & \multirow[b]{2}{*}{$\underset{d 0}{D a}$} & \multirow[b]{2}{*}{$\begin{array}{l}\text { T. } \\
0 \\
0 \\
0 \\
0 \\
0 \\
0 \\
0 \\
0 \\
0 \\
0\end{array}$} & \multirow{2}{*}{ 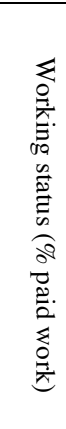 } & \multicolumn{4}{|c|}{ Family types } & \multirow{2}{*}{ 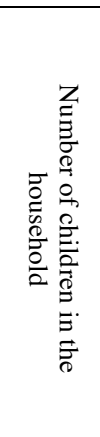 } & \multirow{2}{*}{ 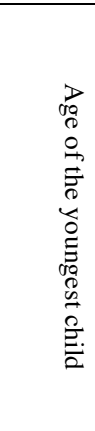 } & \multirow{2}{*}{ 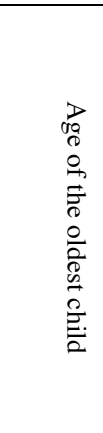 } & \multirow{2}{*}{ 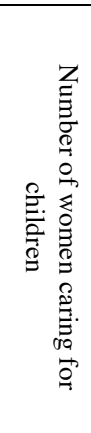 } & \multirow{2}{*}{ 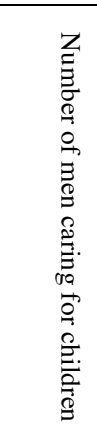 } & \multirow{2}{*}{ 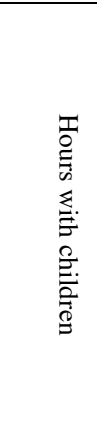 } & \multicolumn{3}{|c|}{$\begin{array}{l}\text { Neighborhood } \\
\text { profiles }\end{array}$} \\
\hline & & & & & 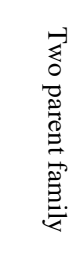 & 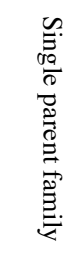 & 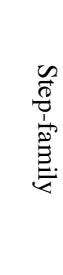 & 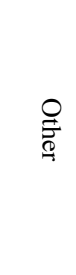 & & & & & & & 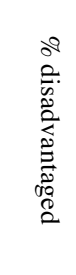 & 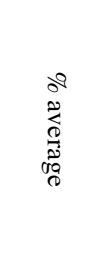 & $\begin{array}{l}0^{9} \\
0 \\
0 \\
0 \\
0 \\
0 \\
0 \\
0\end{array}$ \\
\hline Algeria & 189 & $\begin{array}{l}38.94 \\
(9.99)\end{array}$ & $\begin{array}{l}13.86 \\
(4.74)\end{array}$ & 56.6 & 64.0 & 1.6 & 0 & 34.4 & $\begin{array}{c}2.57 \\
(1.50)\end{array}$ & $\begin{array}{c}6.48 \\
(7.07)\end{array}$ & $\begin{array}{l}11.77 \\
(9.92)\end{array}$ & $\begin{array}{c}1.67 \\
(1.10)\end{array}$ & $\begin{array}{c}1.47 \\
(1.02)\end{array}$ & $\begin{array}{l}10.62 \\
(6.74)\end{array}$ & 4.2 & 84.1 & $\overline{11.6}$ \\
\hline Argentina & 96 & $\begin{array}{l}40.04 \\
(9.55)\end{array}$ & $\begin{array}{l}17.10 \\
(3.83)\end{array}$ & 83.3 & 65.7 & 17.7 & 8.3 & 8.3 & $\begin{array}{c}2.18 \\
(1.10)\end{array}$ & $\begin{array}{l}10.49 \\
(8.38)\end{array}$ & $\begin{array}{l}13.78 \\
(9.81)\end{array}$ & $\begin{array}{r}1.66 \\
(0.99)\end{array}$ & $\begin{array}{c}1.08 \\
(0.74)\end{array}$ & $\begin{array}{l}11.05 \\
(5.35)\end{array}$ & 2.1 & 72.9 & 25.0 \\
\hline Australia & 109 & $\begin{array}{l}44.95 \\
(8.28)\end{array}$ & $\begin{array}{l}13.13 \\
(2.78)\end{array}$ & 50.5 & 64.2 & 24.8 & 7.3 & 3.7 & $\begin{array}{c}1.80 \\
(0.95)\end{array}$ & $\begin{array}{c}8.15 \\
(6.99)\end{array}$ & $\begin{array}{l}11.87 \\
(7.44)\end{array}$ & $\begin{array}{c}1.06 \\
(0.54)\end{array}$ & $\begin{array}{c}0.87 \\
(0.68)\end{array}$ & $\begin{array}{c}7.25 \\
(3.73)\end{array}$ & 4.6 & 77.1 & 18.3 \\
\hline Austria & 165 & $\begin{array}{l}33.19 \\
(5.71)\end{array}$ & $\begin{array}{l}13.16 \\
(2.90)\end{array}$ & 69.1 & 84.9 & 7.3 & 4.2 & 3.6 & $\begin{array}{c}1.58 \\
(0.82)\end{array}$ & $\begin{array}{c}2.39 \\
(3.82)\end{array}$ & $\begin{array}{c}4.23 \\
(4.93)\end{array}$ & $\begin{array}{c}1.07 \\
(0.36)\end{array}$ & $\begin{array}{c}0.96 \\
(0.40)\end{array}$ & $\begin{array}{l}11.02 \\
(4.91)\end{array}$ & 1.8 & 70.9 & 27.3 \\
\hline Belgium & 1358 & $\begin{array}{l}38.12 \\
(7.10)\end{array}$ & $\begin{array}{l}16.60 \\
(2.61\end{array}$ & 90.5 & 78.7 & 11.3 & 7.9 & 2.2 & $\begin{array}{c}2.10 \\
(0.94)\end{array}$ & $\begin{array}{c}5.25 \\
(5.45)\end{array}$ & $\begin{array}{c}8.78 \\
(6.83)\end{array}$ & $\begin{array}{c}1.20 \\
(0.66)\end{array}$ & $\begin{array}{c}0.97 \\
(0.55)\end{array}$ & $\begin{array}{c}5.73 \\
(3.35)\end{array}$ & 2.9 & 47.8 & 49.3 \\
\hline Brazil & 175 & $\begin{array}{l}41.12 \\
(8.41)\end{array}$ & $\begin{array}{c}16.26 \\
(3.66)\end{array}$ & 69.6 & 87.3 & 4.6 & 5.2 & 2.9 & $\begin{array}{c}1.52 \\
(0.72)\end{array}$ & $\begin{array}{c}8.68 \\
(7.37)\end{array}$ & $\begin{array}{l}10.85 \\
(7.81)\end{array}$ & $\begin{array}{c}1.21 \\
(0.53)\end{array}$ & $\begin{array}{c}1.01 \\
(0.50)\end{array}$ & $\begin{array}{c}6.73 \\
(5.05)\end{array}$ & 16.1 & 66.7 & 17.2 \\
\hline Burundi & 93 & $\begin{array}{l}36.75 \\
(9.51)\end{array}$ & $\begin{array}{l}11.04 \\
(4.85)\end{array}$ & 54.8 & 82.8 & 17.2 & 0.0 & 0.0 & $\begin{array}{c}3.66 \\
(2.01)\end{array}$ & $\begin{array}{c}5.22 \\
(5.38)\end{array}$ & $\begin{array}{l}13.13 \\
(8.32)\end{array}$ & $\begin{array}{c}1.68 \\
(1.22)\end{array}$ & $\begin{array}{c}1.29 \\
(0.98)\end{array}$ & $\begin{array}{c}7.38 \\
(4.88)\end{array}$ & 23.2 & 51.2 & 25.6 \\
\hline Cameroun & 99 & $\begin{array}{l}37.10 \\
(8.89)\end{array}$ & $\begin{array}{l}14.11 \\
(3.03)\end{array}$ & 67.7 & 73.5 & 17.4 & 2.0 & 7.1 & $\begin{array}{l}3.70 \\
(2.54)\end{array}$ & $\begin{array}{c}5.64 \\
(6.25)\end{array}$ & $\begin{array}{l}14.13 \\
(8.79)\end{array}$ & $\begin{array}{l}1.68 \\
(1.26)\end{array}$ & $\begin{array}{l}1.07 \\
(0.89)\end{array}$ & $\begin{array}{c}9.90 \\
(5.55)\end{array}$ & 18.2 & 72.7 & 9.1 \\
\hline Canada & 230 & $\begin{array}{l}34.14 \\
(6.73)\end{array}$ & $\begin{array}{l}16.01 \\
(2.73)\end{array}$ & 85.2 & 82.6 & 8.3 & 8.3 & 0.9 & $\begin{array}{c}2.15 \\
(0.87)\end{array}$ & $\begin{array}{c}3.83 \\
(4.42)\end{array}$ & $\begin{array}{c}7.31 \\
(6.08)\end{array}$ & $\begin{array}{c}1.03 \\
(0.45)\end{array}$ & $\begin{array}{c}0.97 \\
(0.41)\end{array}$ & $\begin{array}{c}9.11 \\
(6.72)\end{array}$ & 7.4 & 61.3 & 31.3 \\
\hline Chile & 369 & $\begin{array}{l}35.85 \\
(5.70)\end{array}$ & $\begin{array}{l}17.80 \\
(3.32)\end{array}$ & 73.4 & 71.0 & 12.7 & 7.1 & 9.2 & $\begin{array}{l}1.83 \\
(1.41)\end{array}$ & $\begin{array}{l}4.18 \\
(3.39)\end{array}$ & $\begin{array}{l}7.78 \\
(6.46)\end{array}$ & $\begin{array}{c}1.54 \\
(0.81)\end{array}$ & $\begin{array}{c}0.96 \\
(0.58)\end{array}$ & $\begin{array}{l}11.00 \\
(7.48)\end{array}$ & 2.4 & 59.3 & 38.2 \\
\hline China & 400 & $\begin{array}{l}37.95 \\
(3.97)\end{array}$ & $\begin{array}{l}10.20 \\
(2.93)\end{array}$ & 87.3 & 83.8 & 4.3 & 1.5 & 10.5 & $\begin{array}{c}1.48 \\
(0.60)\end{array}$ & $\begin{array}{l}10.86 \\
(4.05)\end{array}$ & $\begin{array}{l}14.05 \\
(3.57)\end{array}$ & $\begin{array}{c}1.72 \\
(0.87)\end{array}$ & $\begin{array}{c}1.50 \\
(0.79)\end{array}$ & $\begin{array}{c}4.24 \\
(2.70)\end{array}$ & 4.0 & 91.0 & 5.0 \\
\hline Colombia & 63 & - & - & 81.0 & 57.1 & 27.0 & 4.8 & 11.1 & $\begin{array}{c}1.54 \\
(0.78)\end{array}$ & $\begin{array}{c}7.97 \\
(7.13)\end{array}$ & $\begin{array}{c}12.13 \\
(8.27)\end{array}$ & $\begin{array}{c}1.51 \\
(0.78)\end{array}$ & $\begin{array}{c}0.86 \\
(0.80)\end{array}$ & $\begin{array}{c}7.83 \\
(6.28)\end{array}$ & 4.8 & 63.5 & 31.7 \\
\hline Costa Rica & 146 & $\begin{array}{l}35.72 \\
(6.73)\end{array}$ & $\begin{array}{l}17.01 \\
(4.35)\end{array}$ & 78.8 & 71.2 & 8.9 & 6.8 & 13.1 & $\begin{array}{c}1.51 \\
(0.71)\end{array}$ & $\begin{array}{c}6.70 \\
(6.74)\end{array}$ & $\begin{array}{c}8.00 \\
(7.45)\end{array}$ & $\begin{array}{c}1.54 \\
(0.81)\end{array}$ & $\begin{array}{c}1.07 \\
(0.65)\end{array}$ & $\begin{array}{l}10.90 \\
(6.66)\end{array}$ & 3.4 & 67.8 & 28.8 \\
\hline
\end{tabular}


Running head: GENDER EQUALITY AND PARENTAL BURNOUT

\begin{tabular}{|c|c|c|c|c|c|c|c|c|c|c|c|c|c|c|c|c|c|}
\hline Cuba & 138 & $\begin{array}{c}40.04 \\
(10.32)\end{array}$ & $\begin{array}{l}13.86 \\
(3.12)\end{array}$ & $\begin{array}{c}78.2 \\
6\end{array}$ & 47.1 & 12.3 & 15.2 & 25.4 & $\begin{array}{l}1.48 \\
(.60)\end{array}$ & $\begin{array}{l}11.06 \\
(8.14)\end{array}$ & $\begin{array}{l}14.82 \\
(9.46)\end{array}$ & $\begin{array}{c}1.67 \\
(0.80)\end{array}$ & $\begin{array}{c}1.15 \\
(0.73)\end{array}$ & $\begin{array}{l}11.82 \\
(4.68)\end{array}$ & 10.9 & 60.1 & 29.0 \\
\hline Ecuador & 90 & $\begin{array}{l}31.87 \\
(6.95)\end{array}$ & $\begin{array}{l}16.83 \\
(2.92)\end{array}$ & 81.1 & 61.1 & 15.6 & 6.7 & 16.7 & $\begin{array}{c}1.62 \\
(0.71)\end{array}$ & $\begin{array}{c}6.49 \\
(4.41)\end{array}$ & $\begin{array}{c}8.29 \\
(6.52)\end{array}$ & $\begin{array}{c}2.04 \\
(1.13)\end{array}$ & $\begin{array}{c}1.42 \\
(0.97)\end{array}$ & $\begin{array}{c}8.48 \\
(5.40)\end{array}$ & 1.1 & 73.3 & 25.6 \\
\hline Egypt & 150 & $\begin{array}{l}46.83 \\
(5.57)\end{array}$ & $\begin{array}{l}10.81 \\
(3.43)\end{array}$ & 1.33 & 73.3 & 18.0 & 0.7 & 8.0 & $\begin{array}{c}3.05 \\
(1.37)\end{array}$ & $\begin{array}{l}14.74 \\
(6.38)\end{array}$ & $\begin{array}{l}25.06 \\
(5.43)\end{array}$ & $\begin{array}{c}1.39 \\
(1.06)\end{array}$ & $\begin{array}{c}1.25 \\
(1.02)\end{array}$ & $\begin{array}{c}8.93 \\
(4.06)\end{array}$ & 6.7 & 68.7 & 24.7 \\
\hline Finland & 1567 & $\begin{array}{l}36.36 \\
(6.41)\end{array}$ & $\begin{array}{l}17.72 \\
(3.32)\end{array}$ & 73.9 & 78.4 & 9.4 & 9.2 & 3.0 & $\begin{array}{c}2.24 \\
(1.26)\end{array}$ & $\begin{array}{c}4.17 \\
(4.21)\end{array}$ & $\begin{array}{c}7.59 \\
(5.34)\end{array}$ & $\begin{array}{c}0.91 \\
(0.37)\end{array}$ & $\begin{array}{c}0.87 \\
(0.44)\end{array}$ & $\begin{array}{c}7.91 \\
(3.76)\end{array}$ & 0.0 & 99.9 & 0.1 \\
\hline France & 908 & $\begin{array}{l}37.28 \\
(7.66)\end{array}$ & $\begin{array}{l}15.13 \\
(2.71)\end{array}$ & 80.6 & 75.4 & 13.6 & 9.0 & 1.2 & $\begin{array}{c}1.86 \\
(0.83)\end{array}$ & $\begin{array}{c}5.67 \\
(5.44)\end{array}$ & $\begin{array}{c}9.07 \\
(6.94)\end{array}$ & $\begin{array}{c}1.40 \\
(1.10)\end{array}$ & $\begin{array}{c}0.95 \\
(0.65)\end{array}$ & $\begin{array}{c}8.60 \\
(5.34)\end{array}$ & 3.2 & 58.3 & 38.5 \\
\hline Germany & 135 & $\begin{array}{c}34.96 \\
(7.61)\end{array}$ & $\begin{array}{l}13.62 \\
(4.44)\end{array}$ & 69.6 & 72.6 & 15.6 & 6.7 & 5.2 & $\begin{array}{c}1.78 \\
(0.93)\end{array}$ & $\begin{array}{c}4.67 \\
(4.81)\end{array}$ & $\begin{array}{c}7.83 \\
(6.93)\end{array}$ & $\begin{array}{c}1.03 \\
(0.46)\end{array}$ & $\begin{array}{c}0.84 \\
(0.52)\end{array}$ & $\begin{array}{c}8.43 \\
(4.18)\end{array}$ & 4.4 & 76.3 & 19.3 \\
\hline Iran & 223 & $\begin{array}{l}38.28 \\
(7.89)\end{array}$ & $\begin{array}{l}13.60 \\
(3.35)\end{array}$ & 40.4 & 86.6 & 9.4 & 2.2 & 1.8 & $\begin{array}{c}1.72 \\
(0.71)\end{array}$ & $\begin{array}{c}9.44 \\
(7.63)\end{array}$ & $\begin{array}{l}13.99 \\
(9.12)\end{array}$ & $\begin{array}{c}1.13 \\
(0.44)\end{array}$ & $\begin{array}{c}0.98 \\
(0.37)\end{array}$ & $\begin{array}{c}7.68 \\
(3.48)\end{array}$ & 11.7 & 56.6 & 31.7 \\
\hline Italy & 250 & $\begin{array}{l}42.14 \\
(8.26)\end{array}$ & $\begin{array}{l}15.26 \\
(3.94)\end{array}$ & 83.2 & 86.4 & 5.6 & 4.0 & 4.0 & $\begin{array}{c}1.77 \\
(0.72)\end{array}$ & $\begin{array}{c}8.48 \\
(6.66)\end{array}$ & $\begin{array}{l}11.85 \\
(8.54)\end{array}$ & $\begin{array}{c}1.14 \\
(0.56)\end{array}$ & $\begin{array}{c}1.02 \\
(0.42)\end{array}$ & $\begin{array}{c}8.23 \\
(5.51)\end{array}$ & 2.0 & 76.0 & 22.0 \\
\hline Japan & 250 & $\begin{array}{c}53.25 \\
(15.68)\end{array}$ & $\begin{array}{l}13.58 \\
(2.38)\end{array}$ & 40.8 & 71.6 & 13.6 & 2.0 & 12.8 & $\begin{array}{c}1.51 \\
(0.71)\end{array}$ & $\begin{array}{c}13.64 \\
(11.71)\end{array}$ & $\begin{array}{c}23.38 \\
(15.45)\end{array}$ & $\begin{array}{c}1.10 \\
(0.35)\end{array}$ & $\begin{array}{c}0.74 \\
(0.52)\end{array}$ & $\begin{array}{c}6.36 \\
(4.84)\end{array}$ & 1.2 & 86.0 & 12.8 \\
\hline Lebanon & 135 & $\begin{array}{l}36.33 \\
(8.58)\end{array}$ & $\begin{array}{l}16.27 \\
(3.69)\end{array}$ & 52.6 & 92.6 & 5.9 & 0.7 & 0.7 & $\begin{array}{c}2.19 \\
(1.01)\end{array}$ & $\begin{array}{c}8.14 \\
(6.26)\end{array}$ & $\begin{array}{l}10.90 \\
(8.03)\end{array}$ & $\begin{array}{c}1.21 \\
(0.51)\end{array}$ & $\begin{array}{c}1.00 \\
(0.35)\end{array}$ & $\begin{array}{c}8.21 \\
(3.28)\end{array}$ & 4.4 & 71.9 & 23.7 \\
\hline Netherlands & 135 & $\begin{array}{c}36.75 \\
(7.11)\end{array}$ & $\begin{array}{l}16.74 \\
(2.39)\end{array}$ & 93.3 & 88.1 & 5.2 & 3.7 & 3.0 & $\begin{array}{c}1.74 \\
(0.71)\end{array}$ & $\begin{array}{c}4.07 \\
(4.80)\end{array}$ & $\begin{array}{c}6.29 \\
(6.30)\end{array}$ & $\begin{array}{c}1.55 \\
(1.09)\end{array}$ & $\begin{array}{c}1.09 \\
(0.58)\end{array}$ & $\begin{array}{c}6.87 \\
(3.00)\end{array}$ & 3.0 & 50.4 & 46.6 \\
\hline Pakistan & 100 & $\begin{array}{c}48.44 \\
(10.47)\end{array}$ & $\begin{array}{l}11.95 \\
(3.98)\end{array}$ & 40.4 & 71.9 & 12.4 & 2.3 & 13.5 & $\begin{array}{c}4.73 \\
(2.89)\end{array}$ & $\begin{array}{l}12.81 \\
(8.16)\end{array}$ & $\begin{array}{c}20.38 \\
(10.61)\end{array}$ & $\begin{array}{c}2.54 \\
(1.48)\end{array}$ & $\begin{array}{c}2.21 \\
(1.38)\end{array}$ & $\begin{array}{c}8.31 \\
(6.38)\end{array}$ & 25.8 & 61.3 & 12.9 \\
\hline Peru & 198 & $\begin{array}{l}39.00 \\
(9.53)\end{array}$ & $\begin{array}{l}15.05 \\
(4.93)\end{array}$ & 79.8 & 62.6 & 19.2 & 6.1 & 12.1 & $\begin{array}{c}1.96 \\
(1.10)\end{array}$ & $\begin{array}{c}7.98 \\
(7.25)\end{array}$ & $\begin{array}{l}12.28 \\
(8.74)\end{array}$ & $\begin{array}{c}1.97 \\
(1.21)\end{array}$ & $\begin{array}{c}1.35 \\
(1.15)\end{array}$ & $\begin{array}{c}9.45 \\
(5.80)\end{array}$ & 6.1 & 65.2 & 28.8 \\
\hline Poland & 325 & $\begin{array}{l}32.97 \\
(5.31)\end{array}$ & $\begin{array}{l}17.84 \\
(3.35)\end{array}$ & 66.5 & 86.2 & 6.5 & 3.1 & 4.3 & $\begin{array}{c}1.66 \\
(0.98)\end{array}$ & $\begin{array}{c}3.50 \\
(4.05)\end{array}$ & $\begin{array}{c}4.87 \\
(4.70)\end{array}$ & $\begin{array}{c}1.21 \\
(0.89)\end{array}$ & $\begin{array}{c}0.93 \\
(0.61)\end{array}$ & $\begin{array}{c}9.38 \\
(4.91)\end{array}$ & 3.1 & 76.3 & 20.6 \\
\hline Portugal & 204 & $\begin{array}{l}39.50 \\
(7.12)\end{array}$ & $\begin{array}{l}15.86 \\
(3.09)\end{array}$ & 89.1 & 88.1 & 3.5 & 5.9 & 2.5 & $\begin{array}{c}1.71 \\
(0.76)\end{array}$ & $\begin{array}{c}6.01 \\
(5.36)\end{array}$ & $\begin{array}{c}9.00 \\
(7.43)\end{array}$ & $\begin{array}{c}1.01 \\
(0.48)\end{array}$ & $\begin{array}{c}0.88 \\
(0.37)\end{array}$ & $\begin{array}{c}5.44 \\
(3.23)\end{array}$ & 1.0 & 63.9 & 35.1 \\
\hline Romania & 195 & $\begin{array}{l}35.90 \\
(4.94)\end{array}$ & $\begin{array}{l}17.21 \\
(2.57)\end{array}$ & 85.1 & 88.7 & 4.6 & 3.1 & 3.6 & $\begin{array}{c}1.59 \\
(0.62)\end{array}$ & $\begin{array}{c}3.45 \\
(3.90)\end{array}$ & $\begin{array}{c}6.27 \\
(4.93)\end{array}$ & $\begin{array}{c}1.39 \\
(0.76)\end{array}$ & $\begin{array}{c}1.07 \\
(0.63)\end{array}$ & $\begin{array}{c}9.14 \\
(7.26)\end{array}$ & 1.5 & 21.5 & 76.9 \\
\hline Russia & 263 & $\begin{array}{l}33.68 \\
(6.51)\end{array}$ & $\begin{array}{l}14.35 \\
(4.39)\end{array}$ & 77.9 & 75.3 & 9.1 & 8.4 & 7.2 & $\begin{array}{c}1.68 \\
(0.79)\end{array}$ & $\begin{array}{c}4.02 \\
(3.94)\end{array}$ & $\begin{array}{c}7.94 \\
(6.16)\end{array}$ & $\begin{array}{c}1.27 \\
(0.64)\end{array}$ & $\begin{array}{c}1.02 \\
(0.59)\end{array}$ & $\begin{array}{c}9.04 \\
(5.43)\end{array}$ & 0.4 & 60.5 & 39.2 \\
\hline Serbia & 153 & $\begin{array}{l}37.72 \\
(5.48)\end{array}$ & $\begin{array}{l}14.92 \\
(5.22)\end{array}$ & 83.7 & 92.2 & 3.9 & 0 & 3.9 & $\begin{array}{c}1.59 \\
(0.65)\end{array}$ & $\begin{array}{c}4.02 \\
(4.30)\end{array}$ & $\begin{array}{c}6.56 \\
(5.58)\end{array}$ & $\begin{array}{c}1.19 \\
(0.63)\end{array}$ & $\begin{array}{c}1.00 \\
(0.53)\end{array}$ & $\begin{array}{c}8.56 \\
(5.08)\end{array}$ & 2.0 & 47.1 & 51.0 \\
\hline Spain & 337 & $\begin{array}{l}40.14 \\
(8.11)\end{array}$ & $\begin{array}{l}14.87 \\
(4.28)\end{array}$ & 73.4 & 78.1 & 9.9 & 6.0 & 6.0 & $\begin{array}{c}1.75 \\
(0.83)\end{array}$ & $\begin{array}{c}6.88 \\
(6.93)\end{array}$ & $\begin{array}{c}9.80 \\
(8.28)\end{array}$ & $\begin{array}{c}1.37 \\
(1.11)\end{array}$ & $\begin{array}{c}1.00 \\
(0.60)\end{array}$ & $\begin{array}{l}11.52 \\
(7.14)\end{array}$ & 5.8 & 79.3 & 14.9 \\
\hline Sweden & 662 & $\begin{array}{l}40.36 \\
(4.68)\end{array}$ & $\begin{array}{l}15.60 \\
(3.07)\end{array}$ & 86.7 & 75.2 & 10.3 & 8.8 & 5.7 & $\begin{array}{c}2.14 \\
(0.95)\end{array}$ & $\begin{array}{c}6.32 \\
(4.66)\end{array}$ & $\begin{array}{l}11.88 \\
(6.07)\end{array}$ & $\begin{array}{c}1.02 \\
(0.53)\end{array}$ & $\begin{array}{c}1.02 \\
(0.56)\end{array}$ & $\begin{array}{c}6.48 \\
(3.16)\end{array}$ & 4.8 & 74.2 & 20.9 \\
\hline Switzerland & 271 & $\begin{array}{l}39.80 \\
(6.41)\end{array}$ & $\begin{array}{l}16.29 \\
(3.48)\end{array}$ & 98.6 & 79.0 & 14.0 & 6.3 & 0.7 & $\begin{array}{c}2.00 \\
(0.83)\end{array}$ & $\begin{array}{c}6.46 \\
(4.85)\end{array}$ & $\begin{array}{c}9.00 \\
(5.84)\end{array}$ & $\begin{array}{c}1.12 \\
(0.58)\end{array}$ & $\begin{array}{c}0.93 \\
(0.53)\end{array}$ & $\begin{array}{c}6.91 \\
(4.36)\end{array}$ & 0.4 & 49.8 & 49.8 \\
\hline Thailand & 202 & $\begin{array}{l}42.07 \\
(5.27)\end{array}$ & $\begin{array}{c}3.29 \\
(1.03)\end{array}$ & 96.0 & 70.9 & 2.5 & 1.0 & 25.6 & $\begin{array}{c}1.83 \\
(0.69)\end{array}$ & $\begin{array}{c}9.18 \\
(3.79)\end{array}$ & $\begin{array}{l}12.55 \\
(5.00)\end{array}$ & $\begin{array}{c}1.81 \\
(1.00)\end{array}$ & $\begin{array}{c}1.43 \\
(0.79)\end{array}$ & $\begin{array}{c}6.32 \\
(3.69)\end{array}$ & 1.0 & 50.2 & 48.8 \\
\hline Turkey & 269 & $\begin{array}{l}36.68 \\
(6.52)\end{array}$ & $\begin{array}{l}13.75 \\
(3.62)\end{array}$ & 79.2 & 87.3 & 6.3 & 0.4 & 6.0 & $\begin{array}{c}1.65 \\
(0.62)\end{array}$ & $\begin{array}{c}4.03 \\
(3.04)\end{array}$ & $\begin{array}{c}7.46 \\
(5.63)\end{array}$ & $\begin{array}{c}1.15 \\
(0.53)\end{array}$ & $\begin{array}{c}1.03 \\
(0.41)\end{array}$ & $\begin{array}{c}6.07 \\
(2.97)\end{array}$ & 5.2 & 75.1 & 19.7 \\
\hline UK & 163 & $\begin{array}{l}37.55 \\
(7.04)\end{array}$ & $\begin{array}{l}16.00 \\
(3.22)\end{array}$ & 77.3 & 89.6 & 8.0 & 1.8 & 0.6 & $\begin{array}{c}1.78 \\
(0.75)\end{array}$ & $\begin{array}{c}5.23 \\
(5.30)\end{array}$ & $\begin{array}{c}7.44 \\
(6.39)\end{array}$ & $\begin{array}{c}1.04 \\
(0.27)\end{array}$ & $\begin{array}{c}0.94 \\
(0.48)\end{array}$ & $\begin{array}{c}7.79 \\
(4.18)\end{array}$ & 4.9 & 47.2 & 47.9 \\
\hline
\end{tabular}


Running head: GENDER EQUALITY AND PARENTAL BURNOUT

\begin{tabular}{|c|c|c|c|c|c|c|c|c|c|c|c|c|c|c|c|c|c|}
\hline Uruguay & 188 & $\begin{array}{l}34.32 \\
(5.81)\end{array}$ & $\begin{array}{l}13.23 \\
(4.76)\end{array}$ & 86.7 & 73.3 & 15.5 & 4.3 & 6.9 & $\begin{array}{c}1.59 \\
(0.73)\end{array}$ & $\begin{array}{c}2.79 \\
(1.71)\end{array}$ & $\begin{array}{c}6.15 \\
(4.77)\end{array}$ & $\begin{array}{c}1.49 \\
(0.79)\end{array}$ & $\begin{array}{c}1.03 \\
(0.62)\end{array}$ & $\begin{array}{l}12.64 \\
(5.51)\end{array}$ & 3.2 & 71.8 & 25.0 \\
\hline USA & 272 & $\begin{array}{l}36.92 \\
(8.28)\end{array}$ & $\begin{array}{l}15.77 \\
(3.55)\end{array}$ & 72.1 & 70.2 & 18.4 & 6.3 & 5.2 & $\begin{array}{c}1.93 \\
(1.01)\end{array}$ & $\begin{array}{c}6.13 \\
(5.39)\end{array}$ & $\begin{array}{l}10.18 \\
(7.12)\end{array}$ & $\begin{array}{c}1.15 \\
(0.68)\end{array}$ & $\begin{array}{c}0.90 \\
(0.71)\end{array}$ & $\begin{array}{c}7.84 \\
(4.92)\end{array}$ & 7.4 & 71.3 & 21.3 \\
\hline Vietnam & 143 & $\begin{array}{l}35.77 \\
(6.28)\end{array}$ & $\begin{array}{l}14.01 \\
(4.21)\end{array}$ & 93.6 & 78.3 & 2.9 & 0.7 & 18.1 & $\begin{array}{c}1.72 \\
(1.05)\end{array}$ & $\begin{array}{c}5.01 \\
(5.79)\end{array}$ & $\begin{array}{l}7.94 \\
(.86)\end{array}$ & $\begin{array}{c}1.40 \\
(0.86)\end{array}$ & $\begin{array}{c}1.18 \\
(0.72)\end{array}$ & $\begin{array}{c}5.26 \\
(3.148\end{array}$ & 3.5 & 40.4 & 56.0 \\
\hline $\begin{array}{l}\text { Pooled } \\
\text { Sample }\end{array}$ & 11,538 & $\begin{array}{l}38.09 \\
(8.08)\end{array}$ & $\begin{array}{l}15.32 \\
(4.18)\end{array}$ & 76.8 & 77.7 & 10.3 & 6.1 & 1.5 & $\begin{array}{c}1.96 \\
(1.10)\end{array}$ & $\begin{array}{c}6.24 \\
(6.60)\end{array}$ & $\begin{array}{c}9.79 \\
(7.89)\end{array}$ & $\begin{array}{c}1.27 \\
(0.80)\end{array}$ & $\begin{array}{c}1.02 \\
(0.65)\end{array}$ & $\begin{array}{c}7.90 \\
(5.07)\end{array}$ & 3.9 & 68.7 & 78.4 \\
\hline
\end{tabular}


Table 2. Country Mean Level of Parental Burnout, Gender Equality, GDP per capita for Each Country.

\begin{tabular}{lccc}
\hline & $\begin{array}{c}\text { Parental } \\
\text { Burnout }\end{array}$ & $\begin{array}{c}\text { Gender } \\
\text { Equality }\end{array}$ & $\begin{array}{c}\text { GDP per } \\
\text { capita }\end{array}$ \\
\cline { 2 - 4 } Algeria & 20.81 & .629 & 4153.96 \\
Argentina & 20.73 & .732 & 11633.50 \\
Australia & 30.00 & .730 & 57354.96 \\
Austria & 22.79 & .718 & 51453.15 \\
Belgium & 38.91 & .739 & 47554.75 \\
Brazil & 20.41 & .681 & 9151.45 \\
Burundi & 34.41 & .755 & 271.75 \\
Cameroon & 18.09 & .689 & 1534.49 \\
Canada & 32.35 & .769 & 46454.74 \\
Chile & 31.59 & .704 & 15888.14 \\
China & 11.51 & .674 & 9976.68 \\
Colombia & 19.38 & .729 & 6729.58 \\
Costa Rica & 30.99 & .727 & 12468.58 \\
Cuba & 6.95 & .745 & 8824.19 \\
Ecuador & 21.08 & .724 & 6295.93 \\
Egypt & 42.58 & .608 & 2537.13 \\
Finland & 32.67 & .823 & 50013.29 \\
France & 32.34 & .778 & 41526.41 \\
Germany & 26.96 & .776 & 47787.16 \\
Iran & 16.84 & .583 & 3598.48 \\
Italy & 18.28 & .692 & 34608.68 \\
Japan & 15.69 & .657 & 39159.42 \\
Lebanon & 20.44 & .596 & 8012.54 \\
Pakistan & 16.27 & .546 & 1482.21 \\
Peru & 21.5 & .719 & 6957.79 \\
Poland & 42.47 & .728 & 15468.41 \\
Portugal & 24.90 & .732 & 23551.05 \\
Romania & 26.61 & .708 & 12398.98 \\
Russia & 30.47 & .696 & 11287.36 \\
Serbia & 21.50 & .730 & 7252.4 \\
Spain & 30.80 & .746 & 30374.52 \\
Sweden & 21.03 & .822 & 54589.06 \\
Switzerland & 36.21 & .755 & 86429.50 \\
Thailand & 6.20 & .694 & 7296.88 \\
The Netherlands & 21.24 & .737 & 53018.63 \\
Turkey & 12.41 & .627 & 9453.20 \\
UK & 29.63 & .770 & 42992.80 \\
Uruguay & 13.43 & .710 & 18703.86 \\
USA & 30.33 & .718 & 63064.42 \\
Vietnam & 15.51 & .698 & 2566.45 \\
\hline & & &
\end{tabular}


Table 3. Partial Correlations between Egalitarian Values and Parental Burnout at the Individual Level Accounting for Sociodemographic Characteristics for Each Country.

\begin{tabular}{|c|c|c|c|}
\hline Country & $r$ & $R^{2}$ & $p$ \\
\hline Algeria & -.05 & .48 & .00 \\
\hline Argentina & -.05 & .00 & .66 \\
\hline Australia & .19 & .04 & .06 \\
\hline Austria & .10 & .01 & .24 \\
\hline Belgium & .18 & .03 & $<.001$ \\
\hline Brazil & .30 & .09 & .09 \\
\hline Burundi & .02 & .00 & .88 \\
\hline Cameroon & .13 & .02 & .21 \\
\hline Canada & .18 & .03 & .01 \\
\hline Chile & .09 & .01 & .07 \\
\hline China & .03 & .00 & .61 \\
\hline Colombia & .11 & .01 & .19 \\
\hline Costa Rica & .11 & .01 & .19 \\
\hline Cuba & -.03 & .00 & .77 \\
\hline Ecuador & .19 & .04 & .09 \\
\hline Egypt & .28 & .08 & .001 \\
\hline Finland & .14 & .02 & $<.001$ \\
\hline France & .14 & .02 & $<.001$ \\
\hline Germany & .22 & .05 & .02 \\
\hline Iran & -.01 & .00 & .89 \\
\hline Italy & .14 & .02 & .03 \\
\hline Japan & .17 & .03 & .01 \\
\hline Lebanon & .33 & .11 & $<.001$ \\
\hline Netherlands & .13 & .02 & .18 \\
\hline Pakistan & -.27 & .07 & .20 \\
\hline Peru & -.01 & .00 & .89 \\
\hline Poland & .21 & .04 & $<.001$ \\
\hline Portugal & .18 & .03 & .02 \\
\hline Romania & .23 & .05 & .001 \\
\hline Russia & .25 & .06 & $<.001$ \\
\hline Serbia & .20 & .04 & .02 \\
\hline Spain & .03 & .00 & .59 \\
\hline Sweden & .18 & .03 & $<.001$ \\
\hline Switzerland & .17 & .03 & .01 \\
\hline Thailand & -.01 & .00 & .94 \\
\hline Turkey & .06 & .00 & .34 \\
\hline UK & .24 & .06 & .002 \\
\hline Uruguay & -.03 & .00 & .70 \\
\hline USA & .11 & .01 & .08 \\
\hline Vietnam & .04 & .00 & .70 \\
\hline Pooled sample & .15 & .02 & $<.001$ \\
\hline
\end{tabular}

Note. The $r$ coefficient estimates the correlation that would be observed between parental burnout and egalitarian values if the sociodemographic characteristics did not vary. The $\mathrm{R}^{2}$ is the decrease in the model's $\mathrm{R}^{2}$ value that results from removing egalitarian values from the full model. 
Running head: GENDER EQUALITY AND PARENTAL BURNOUT

Table 4. Spearman's Rank Correlation between the Study Variables at the Individual Level.

\begin{tabular}{|c|c|c|c|c|c|c|c|c|c|c|c|}
\hline & $(1)$ & $(2)$ & $(3)$ & $(4)$ & $(5)$ & $(6)$ & $(7)$ & $(8)$ & $(9)$ & $(10)$ & $(11)$ \\
\hline (1) Parental burnout & - & & & & & & & & & & \\
\hline (2) Age & -.11 & - & & & & & & & & & \\
\hline (3) Educational level & .15 & -.02 & - & & & & & & & & \\
\hline (4) Neighborhood & -.01 & .05 & .12 & - & & & & & & & \\
\hline (5) Working status & .05 & -.08 & -.18 & -.10 & - & & & & & & \\
\hline (6) Number of children in the household & .14 & .19 & .01 & .01 & .05 & - & & & & & \\
\hline (7) Family types & .01 & .08 & -.08 & -.06 & .00 & .01 & - & & & & \\
\hline (8) Age of the youngest child & -.19 & .66 & -.19 & -.02 & -.06 & .00 & .19 & - & & & \\
\hline (9) Number of women caring for children & -.08 & -.07 & -.07 & .05 & -.07 & -.02 & .15 & .00 & - & & \\
\hline (10) Number of men caring for children & -.09 & -.11 & -.07 & .03 & -.03 & .05 & -.18 & -.08 & .45 & - & \\
\hline (11) Hours with children & .04 & -.27 & -.02 & -.07 & .35 & .03 & -.04 & -.34 & -.01 & -.00 & - \\
\hline (12) Egalitarian values & .17 & .05 & .17 & .06 & -.17 & -.03 & .08 & .00 & .02 & -.08 & -.06 \\
\hline
\end{tabular}


Running head: GENDER EQUALITY AND PARENTAL BURNOUT

Table 5. Results of Multilevel Random Coefficient Model Predicting Parental Burnout among Mothers

\begin{tabular}{|c|c|c|c|c|c|c|c|c|}
\hline & \multicolumn{2}{|c|}{ Unconditional Model } & \multicolumn{2}{|c|}{$\begin{array}{c}\text { Conditional } \\
\text { Model } 1 \\
\end{array}$} & \multicolumn{2}{|c|}{$\begin{array}{c}\text { Conditional } \\
\text { Model } 2 \\
\end{array}$} & \multicolumn{2}{|c|}{$\begin{array}{c}\text { Conditional } \\
\text { Model } 3 \\
\end{array}$} \\
\hline & Estimate & $\mathrm{SE}$ & Estimate & $\mathrm{SE}$ & Estimate & $\mathrm{SE}$ & Estimate & $\mathrm{SE}$ \\
\hline \multicolumn{9}{|l|}{ Fixed Part } \\
\hline Intercept & 24.41 & 1.22 & 26.01 & 2.85 & 6.44 & 3.15 & -28.91 & 14.11 \\
\hline \multicolumn{9}{|l|}{ Individual Level } \\
\hline Age & & & -.07 & .05 & -.10 & .05 & -.11 & .05 \\
\hline Educational Level & & & .04 & .08 & -.05 & .08 & -.05 & .08 \\
\hline Working Status & & & $4.76^{* * *}$ & .71 & $5.83 * * *$ & .71 & $5.90 * * *$ & .71 \\
\hline Number of Children & & & $2.08 * * *$ & .27 & $2.25 * * *$ & .27 & $2.26 * * *$ & .27 \\
\hline Age Youngest Child & & & $-.42 * * *$ & .07 & $-.40 * * *$ & .07 & $-.39 * * *$ & .07 \\
\hline Number of Hours With Children & & & .00 & .06 & .02 & .06 & .02 & .06 \\
\hline Number of Women In Household & & & -.01 & .41 & -.06 & .40 & -.01 & .40 \\
\hline Number of Men In Household & & & $-2.39 * * *$ & .49 & $-2.02 * * *$ & .49 & $-2.00 * * *$ & .49 \\
\hline Family Type & & & .42 & .19 & .34 & .19 & .32 & .19 \\
\hline Neighborhood & & & $-2.15 * * *$ & .55 & $-2.01 * * *$ & .55 & $-.1 .96 * * *$ & .55 \\
\hline Egalitarian Values & & & & & $3.67 * * *$ & .26 & $3.69 * * *$ & .26 \\
\hline \multicolumn{9}{|l|}{ Societal Level } \\
\hline GDP per capita & & & & & & & $.000 *$ & .000 \\
\hline Gender Equality & & & & & & & $44.52 *$ & 20.30 \\
\hline Egalitarian Values *Gender Equality & & & & & & & $.55^{*}$ & .27 \\
\hline \multicolumn{9}{|l|}{ Random Part } \\
\hline$\sqrt{\bar{\psi}}$ (between countries) & 6.98 & & 6.59 & & 6.44 & & 4.92 & \\
\hline$\frac{\sqrt{\varphi}}{\sqrt{\theta}}$ (within countries) & 26.00 & & 25.73 & & 25.48 & & 25.4 & \\
\hline \multicolumn{9}{|l|}{ Derived estimates } \\
\hline$R_{2}^{2}$ (between countries) & & & $10.86 \%$ & & 14.88 & & 50.31 & \\
\hline$R_{1}^{2}($ within countries $)$ & & & $2.06 \%$ & & $3.96 \%$ & & $3.96^{\circ}$ & \\
\hline$\rho$ & .07 & & .06 & & .06 & & .04 & \\
\hline
\end{tabular}

Note. $* p<.05 * * p<.01 * * * p<.001$. The first model is the unconditional model with no predictor. This baseline model is useful to estimate the reduction in prediction error variance comparing the model without covariates (unconditional model) with the model of interest (i.e. Conditional Models 1 to 3 ). The percentage of variance explained between countries $\left(R_{2}^{2}\right)$ and within countries $\left(R_{1}^{2}\right)$ at each step is indicated in the second part of Table 1 . Greater values indicate greater explanatory power. $R_{2}^{2}$ refers to the

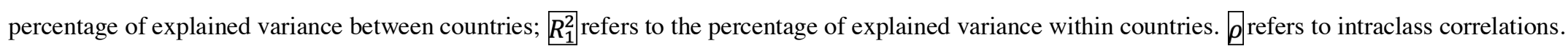


Running head: GENDER EQUALITY AND PARENTAL BURNOUT

\section{Supplemental Material}

Content

Table S1. Ethics Approval in Each Country

Table S2. Data Collection Procedure in Each Country

Table S3. Fit Indices for the Egalitarian Values Model in each Country 
Table S1. Ethics Approval in Each Country

\begin{tabular}{|c|c|c|}
\hline & Name of the Ethics committee & Reference number \\
\hline $\begin{array}{l}\text { Algeria } \\
\text { Argentina }\end{array}$ & $\begin{array}{c}\text { Conseil scientifique du Centre de Recherche en Anthropologie Sociale et Culturelle (CRASC) Oran } \\
\text { Not requested }\end{array}$ & 012/CRASC/DAR/DSRFR/SSR/2018 \\
\hline Australia & The University of Sydney Human Research & $2019 / 062$ \\
\hline Austria & Research Ethics at the University of Klagenfurt & 2019-014 \\
\hline Belgium & Psychological Sciences Research Institute & $2017 / 24$ \\
\hline & Faculty of Psychology and Educational Sciences, Ghent University & 2018/20/Charlotte Schrooyen \\
\hline Brazil & Faculdade de Filosofia, Ciências e Letras de Ribeirão Preto & CAAE: 12579119.5 .0000 .5407 \\
\hline & Universidade de São Paulo & CAAE: $99681118 .-0.5504,3.022 .455$ \\
\hline & Universidade do Estado do Rio de Janeiro - UERJ & CAAE: 97550818.3 .0000 .5282 \\
\hline Burundi & Not requested & \\
\hline Cameroun & Comité National d'Ethique & 576 \\
\hline Canada & $\begin{array}{c}\text { Comité d'éthique de la recherche avec des êtres humains, Décanat de la recherche et de la création de } \\
\text { l'Université du Québec à Trois-Rivières }\end{array}$ & CER-18-242-07.07 \\
\hline Chile & Universidad Autonoma de Chile-Ethics Committee & $71-18$ \\
\hline China & Not requested & \\
\hline Colombia & Not requested & \\
\hline Costa Rica & Comité Ético Científico de la Universidad de Costa Rica, Rodrigo Facio Campus, San Pedro, San José & VI-1071-2018 \\
\hline Cuba & $\begin{array}{c}\text { Comité d'éthique de Recherche et de Publication de la Faculté de psychologie de l'Université de La } \\
\text { Havane }\end{array}$ & 3 \\
\hline Ecuador & Not requested & \\
\hline Egypt & Psychology department Faculty of Arts Menoufia university & $\begin{array}{l}\text { No reference number provided by the Ethics } \\
\text { committee }\end{array}$ \\
\hline Finland & University of Jyväskylä & $\begin{array}{l}\text { No reference number provided by the Ethics } \\
\text { committee }\end{array}$ \\
\hline France & Comité d'éthique pour les recherches comportementales et en santé (CERCES), Université de Paris & $2018-29$ \\
\hline Germany & Universität Ulm Ethikkommission & $21 / 19$ \\
\hline Iran & Not requested & \\
\hline
\end{tabular}




\begin{tabular}{|c|c|c|}
\hline Italy & Psychological Research of the University of Padova & $\begin{array}{c}\text { 2527/2018, } \\
\text { 94A4CED55F19F317187A28C382244070 }\end{array}$ \\
\hline \multirow[t]{2}{*}{ Japan } & Experimental Research on Human Subject & $420-4$ \\
\hline & Graduate School of Arts and Sciences/College of Arts and Sciences, The University of Tokyo & \\
\hline Lebanon & Université Saint-Joseph, Beyrouth (USJ) & 2017-168 \\
\hline Netherlands & School of Social and Behavioral Sciences of Tilburg University & EC-2018.13 \\
\hline Pakistan & Not requested & \\
\hline Peru & Not requested & \\
\hline Poland & SWPS University of Social Sciences and Humanities, Faculty in Sopot & WKE/S 8/II/37 \\
\hline Portugal & Faculdade de Psicologia e de Ciências da Educação da Universidade do Porto & $2017 / 12-12$ \\
\hline Romania & University of Bucharest, Reg.No.CEC: 02/12.01.2018 & \\
\hline Russia & Health et Humane Services IRB00003875St.PetersburgStateUniversity IRB\#1 - Behavioral & 81 \\
\hline Serbia & Department of Psychology, Faculty of Philosophy, University of Belgrade & \#2018-016 \\
\hline \multirow[t]{2}{*}{ Spain } & University of the Basque Country, M10/2017/209 & 6-2018 \\
\hline & $\begin{array}{c}\text { Comité de Ética de la Investigación de la Universidad Nacional de Educación a Distancia (UNED, } \\
\text { ESPAÑA) }\end{array}$ & \\
\hline Sweden & The regional ethic-committee in Gothenburg & DNR 1010-18 \\
\hline Switzerland & Ethical Committe from the State of Vaud & 2018-00186 \\
\hline Thailand & Chiang Mai University Research Ethic Committee, CMUREC & $61 / 046$ \\
\hline Turkey & Bahcesehir University & $18.01 .2018,20021704-604.01 .01-125$ \\
\hline UK & University College London (UCL) Division of Psychology and Language Sciences & CEHP/EP/2018/0004 \\
\hline Uruguay & Ethics Committee of the Faculty of Psychology of the University of the Republic & $\begin{array}{l}\text { No reference number provided by the Ethics } \\
\text { committee }\end{array}$ \\
\hline USA & Stanford University IRB & IRB2-eProtocol 44889 \#Registration 349 \\
\hline & $\begin{array}{l}\text { Administrative Panel on Human Subjects in Non-Medical Research Rosary Santicruz David BA, Sime } \\
\text { Luketa RA, \#: IRB Parental burnout 44889; Florida International University IRB }\end{array}$ & IRB-18-0472 \\
\hline Vietnam & Ho Chi Minh City, Vietnam, Association of Educational Psychology of Ho Chi Minh City (AEPH) & $\begin{array}{l}\text { No reference number provided by the Ethics } \\
\text { committee }\end{array}$ \\
\hline
\end{tabular}


Running head: GENDER EQUALITY AND PARENTAL BURNOUT

Table S2. Data Collection Procedure in Each Country

\begin{tabular}{|c|c|c|c|c|c|c|c|c|c|}
\hline & $\begin{array}{l}\text { Translation } \\
\text { and back- } \\
\text { translation }\end{array}$ & $\begin{array}{c}\text { Survey } \\
\text { Language }\end{array}$ & $\begin{array}{l}\text { Sampling } \\
\text { Procedure }\end{array}$ & Location of Data Collection & Survey Type (\% Online & & $\begin{array}{l}\text { Response } \\
\text { Rate (\%) }\end{array}$ & $\begin{array}{l}\text { Attrition } \\
\text { Rate (\%) }\end{array}$ & $\begin{array}{l}\text { Period of } \\
\text { Data } \\
\text { Collection }\end{array}$ \\
\hline Algeria & Yes & Yes & Arabic & Snowball & $\begin{array}{l}\text { Oran, Mostaganem, } \\
\text { Tlemcen, Ain } \\
\text { Temouchent, Relizane, } \\
\text { Chlef, El Bayadh, } \\
\text { Annaba, Constantine } \\
\text { et Oum El Bouaghi }\end{array}$ & 0 & 90 & 5 & $\begin{array}{c}\text { March-May } \\
2018\end{array}$ \\
\hline Argentina & Yes & Spanish & $\begin{array}{l}\text { Snowball and } \\
\text { convenience }\end{array}$ & San Miguel de Tucumán & 100 & & $\begin{array}{c}\text { Not } \\
\text { applicable }\end{array}$ & 29 & $\begin{array}{c}\text { December } \\
\text { 2018-March } \\
\text { 2019 }\end{array}$ \\
\hline Australia & Not applicable & English & Snowball & $\begin{array}{l}\text { New South Wales, Victoria, } \\
\text { Queensland, Western Australia, } \\
\text { South Australia, Tasmania, } \\
\text { Australian Capital Territory }\end{array}$ & 100 & & $\begin{array}{c}\text { Not } \\
\text { applicable }\end{array}$ & 45.6 & May 2019 \\
\hline Austria & Yes & German & $\begin{array}{l}\text { Snowball and } \\
\text { convenience }\end{array}$ & Undefined & 100 & & $\begin{array}{c}\text { Not } \\
\text { applicable }\end{array}$ & 50.8 & $\begin{array}{l}\text { February- } \\
\text { May } 2019\end{array}$ \\
\hline Belgium & $\begin{array}{l}\text { Yes (Dutch } \\
\text { version)-Not } \\
\text { applicable } \\
\text { (French } \\
\text { version) }\end{array}$ & $\begin{array}{l}\text { French } \\
\text { Dutch }\end{array}$ & Snowball & Flanders and Wallonia & 100 & & $\begin{array}{c}\text { Not } \\
\text { applicable }\end{array}$ & 26 & $\begin{array}{l}\text { February- } \\
\text { June } 2018\end{array}$ \\
\hline Brazil & Yes & Portuguese & $\begin{array}{l}\text { Snowball and } \\
\text { convenience }\end{array}$ & $\begin{array}{c}\text { São Paulo and Rio de Janeiro } \\
\text { states: Amazonas, Ceará, Mato } \\
\text { Grosso do Sul, Minas Gerais, } \\
\text { Paraíba, Paraná, Pernambuco, } \\
\text { Piauí, Rio de Janeiro, São } \\
\text { Paulo, Sergipe }\end{array}$ & 65.1 & & $\begin{array}{c}\text { Not } \\
\text { applicable }\end{array}$ & $\begin{array}{c}\text { Not } \\
\text { available }\end{array}$ & $\begin{array}{c}\text { November } \\
\text { 2018-March } \\
\text { 2019 }\end{array}$ \\
\hline Burundi & Not requested & $\begin{array}{c}\text { Not } \\
\text { applicable }\end{array}$ & French & Stratified & $\begin{array}{l}\text { Bujumbura Mairie, } \\
\text { Bujumbura rural, } \\
\text { Bururi, and Rutana }\end{array}$ & 0 & $\begin{array}{c}\text { Not } \\
\text { applicable }\end{array}$ & 0 & $\begin{array}{l}\text { February- } \\
\text { March } 2020\end{array}$ \\
\hline
\end{tabular}


Running head: GENDER EQUALITY AND PARENTAL BURNOUT

\begin{tabular}{|c|c|c|c|c|c|c|c|c|c|}
\hline Cameroun & Yes & $\begin{array}{c}\text { Not } \\
\text { applicable }\end{array}$ & French & Convenience & Yaounde & 0 & 61 & 11 & $\begin{array}{l}\text { December } \\
\text { 2017-April } \\
2018\end{array}$ \\
\hline Canada & Not applicable & French & Snowball & $\begin{array}{c}\text { Ontario, Manitoba, } \\
\text { Saskatchewan, Alberta, } \\
\text { Québec, territoires du Nord- } \\
\text { Ouest }\end{array}$ & 100 & & $\begin{array}{c}\text { Not } \\
\text { applicable }\end{array}$ & 55 & $\begin{array}{l}\text { May- } \\
\text { December } \\
2018\end{array}$ \\
\hline Chile & Yes & Spanish & $\begin{array}{l}\text { Snowball and } \\
\text { convenience }\end{array}$ & $\begin{array}{l}\text { Santiago, Los Lagos (Puerto } \\
\text { Montt), Del Maule (Talca) }\end{array}$ & 100 & & $\begin{array}{c}\text { Not } \\
\text { applicable }\end{array}$ & 56 & $\begin{array}{l}\text { February- } \\
\text { October } \\
2018\end{array}$ \\
\hline China & Yes & Chinese & Convenience & Zhejiang & 100 & & 77 & 16 & $\begin{array}{l}\text { January } \\
2018\end{array}$ \\
\hline Colombia & Yes & Spanish & $\begin{array}{l}\text { Snowball and } \\
\text { convenience }\end{array}$ & Undefined & 100 & & $\begin{array}{c}\text { Not } \\
\text { applicable }\end{array}$ & $\begin{array}{c}\text { Not } \\
\text { available }\end{array}$ & $\begin{array}{l}\text { December } \\
\text { 2017-April } \\
2018\end{array}$ \\
\hline Costa Rica & Yes & Spanish & $\begin{array}{l}\text { Snowball and } \\
\text { convenience }\end{array}$ & $\begin{array}{c}\text { San José, San Ramon, Heredia, } \\
\text { Cartago, Alajuela }\end{array}$ & 94 & & $\begin{array}{c}\text { Not } \\
\text { applicable }\end{array}$ & 88 & $\begin{array}{l}\text { March-June } \\
2018\end{array}$ \\
\hline Cuba & Yes & Yes & Spanish & Snowball and convenience & $\begin{array}{l}\text { La Havane, Mariel } \\
\text { (Artemesia) }\end{array}$ & 0 & 98.3 & 1 & $\begin{array}{l}\text { September- } \\
\text { December } \\
2018\end{array}$ \\
\hline Ecuador & Yes & Spanish & Convenience & $\begin{array}{c}\text { Quito, Latacunga, Ibarra } \\
\text { Otavalo, Saquisilí, Salcedo, El } \\
\text { corazón, Guaranda, Tulcán, } \\
\text { Cuenca, Guayaquil, Portoviejo, } \\
\text { Esmeraldas, Lago } \\
\text { Agrio/Sucumbíos, Puyo }\end{array}$ & 100 & & $\begin{array}{c}\text { Not } \\
\text { applicable }\end{array}$ & 40 & $\begin{array}{l}\text { March- } \\
\text { September } \\
2018\end{array}$ \\
\hline Egypt & Yes & Arabic & $\begin{array}{l}\text { Snowball and } \\
\text { convenience }\end{array}$ & $\begin{array}{l}\text { Menoufia regions- } 10 \text { cites; } \\
\text { Shebin el kom, Sadat, } \\
\text { Menoufa, Bagour, Ashmon, } \\
\text { Quessna, Shodaa, sir elayan, } \\
\text { Tala, and birkt-elsaba }\end{array}$ & 0 & & 90 & 10 & $\begin{array}{l}\text { February- } \\
\text { March } 2020\end{array}$ \\
\hline Finland & Yes & Finnish & $\begin{array}{l}\text { Snowball and } \\
\text { convenience }\end{array}$ & Hyvinkää, Posio, Jyväskylä & 86.3 & & 99.4 & $\begin{array}{c}\text { Not } \\
\text { available }\end{array}$ & $\begin{array}{l}\text { February- } \\
\text { April } 2018\end{array}$ \\
\hline France & Not applicable & French & $\begin{array}{l}\text { Snowball and } \\
\text { convenience }\end{array}$ & $\begin{array}{l}\text { Provence-Alpes-Côte d'Azur, } \\
\text { Ile-de-France }\end{array}$ & 100 & & $\begin{array}{l}\text { Not } \\
\text { applicable }\end{array}$ & 33 & $\begin{array}{c}\text { January-July } \\
2018\end{array}$ \\
\hline Germany & Yes & German & Convenience & Ulm, Baden-Württemberg & 100 & & 20 & 49 & $\begin{array}{l}\text { May- } \\
\text { November } \\
2019\end{array}$ \\
\hline
\end{tabular}


Running head: GENDER EQUALITY AND PARENTAL BURNOUT

\begin{tabular}{|c|c|c|c|c|c|c|c|c|}
\hline Iran & Yes & Persan & Convenience & Tehran & 0 & $\begin{array}{c}\text { Not } \\
\text { available }\end{array}$ & 3 & $\begin{array}{l}\text { August- } \\
\text { September } \\
2018\end{array}$ \\
\hline Italy & Yes & Italian & $\begin{array}{l}\text { Snowball and } \\
\text { convenience }\end{array}$ & Padova & 98 & $\begin{array}{c}\text { Not } \\
\text { applicable }\end{array}$ & 28 & $\begin{array}{l}\text { March- } \\
\text { December } \\
2018\end{array}$ \\
\hline Japan & Yes & Japanese & $\begin{array}{l}\text { Quota } \\
\text { sampling (by a } \\
\text { research } \\
\text { company) }\end{array}$ & The 47 prefectures in Japan & 100 & $\begin{array}{c}\text { Not } \\
\text { applicable }\end{array}$ & 34 & July 2018 \\
\hline Lebanon & Yes & $\begin{array}{l}\text { French } \\
\text { Arabic }\end{array}$ & Stratified & $\begin{array}{c}\text { Mont Liban, Beyrouth, Liban } \\
\text { North, Liban South, Nabatieh, } \\
\text { Beqaa }\end{array}$ & 100 & 46 & $\begin{array}{c}\text { Not } \\
\text { available }\end{array}$ & $\begin{array}{l}\text { August- } \\
\text { September } \\
2018\end{array}$ \\
\hline Netherlands & Yes & Dutch & $\begin{array}{l}\text { Snowball and } \\
\text { convenience }\end{array}$ & Tilburg & 100 & $\begin{array}{c}\text { Not } \\
\text { applicable }\end{array}$ & 28 & $\begin{array}{l}\text { March 2018- } \\
\text { February } \\
2019\end{array}$ \\
\hline Pakistan & Yes & Urdu & Convenience & Lahore & 0 & 98 & 0 & July 2018 \\
\hline Peru & Yes & Spanish & Convenience & $\begin{array}{l}\text { Lima, Arequipa, Cajamarca, } \\
\text { San Martin, La Libertad, } \\
\text { Lambayeque }\end{array}$ & 46 & $\begin{array}{c}\text { Not } \\
\text { available }\end{array}$ & 19 & $\begin{array}{l}\text { February- } \\
\text { May } 2018\end{array}$ \\
\hline Poland & Yes & Polish & $\begin{array}{l}\text { Snowball and } \\
\text { convenience }\end{array}$ & Warsaw & 85 & $\begin{array}{c}\text { Not } \\
\text { available }\end{array}$ & 1 & $\begin{array}{l}\text { February- } \\
\text { June } 2018\end{array}$ \\
\hline Portugal & Yes & Portuguese & $\begin{array}{l}\text { Snowball and } \\
\text { convenience }\end{array}$ & Coimbra, Porto & 81 & $\begin{array}{l}50 \text { (for } \\
\text { paper pencil } \\
\text { version) }\end{array}$ & 22 & $\begin{array}{l}\text { April- } \\
\text { December } \\
2018\end{array}$ \\
\hline Romania & Yes & Romanian & Convenience & Bucharest, Timisoara & 86 & $\begin{array}{c}\text { Not } \\
\text { available }\end{array}$ & 51 & $\begin{array}{l}\text { December } \\
\text { 2017-May } \\
2018\end{array}$ \\
\hline Russia & Yes & Russian & $\begin{array}{l}\text { Snowball and } \\
\text { convenience }\end{array}$ & Undefined & 100 & $\begin{array}{c}\text { Not } \\
\text { applicable }\end{array}$ & $<1$ & $\begin{array}{l}\text { April- } \\
\text { December } \\
2018\end{array}$ \\
\hline Serbia & Yes & Serbian & $\begin{array}{l}\text { Snowball and } \\
\text { convenience }\end{array}$ & Belgrade & 100 & $\begin{array}{c}\text { Not } \\
\text { applicable }\end{array}$ & 22 & $\begin{array}{l}\text { November } \\
\text { 2018-June } \\
2019\end{array}$ \\
\hline Spain & Yes & Spanish & $\begin{array}{l}\text { Snowball and } \\
\text { convenience }\end{array}$ & $\begin{array}{l}\text { Spain (undefined) and Basque } \\
\text { Country (Galdakao and Igorre, } \\
\text { Azpeitia and Errenteria, } \\
\text { Vitoria-Gasteiz, Leitza) }\end{array}$ & 68 & 15 & 23.4 & $\begin{array}{l}\text { February - } \\
\text { September } \\
2018\end{array}$ \\
\hline
\end{tabular}


Running head: GENDER EQUALITY AND PARENTAL BURNOUT

\begin{tabular}{|c|c|c|c|c|c|c|c|c|}
\hline Sweden & Yes & Swedish & Snowball & Undefined & 100 & $\begin{array}{c}\text { Not } \\
\text { applicable }\end{array}$ & 27 & $\begin{array}{c}\text { March-May } \\
2019\end{array}$ \\
\hline Switzerland & Not applicable & French & $\begin{array}{l}\text { Snowball and } \\
\text { convenience }\end{array}$ & Canton of Vaud & 100 & $\begin{array}{c}\text { Not } \\
\text { applicable }\end{array}$ & 44 & $\begin{array}{l}\text { May- } \\
\text { October }\end{array}$ \\
\hline Thailand & Yes & Thai & Convenience & Chiand Mai & 0 & $\begin{array}{c}\text { Not } \\
\text { available }\end{array}$ & 0 & $\begin{array}{l}2018 \\
\text { July- } \\
\text { September } \\
2018\end{array}$ \\
\hline Turkey & Yes & Turkish & Convenience & Ankara, Istanbul & 0 & 63 & 5 & $\begin{array}{l}\text { April-June } \\
2018\end{array}$ \\
\hline UK & Not applicable & English & $\begin{array}{l}\text { Snowball and } \\
\text { convenience }\end{array}$ & $\begin{array}{c}\text { England, Scotland, Wales and } \\
\text { Northern Ireland }\end{array}$ & 100 & $\begin{array}{l}\text { Not } \\
\text { applicable }\end{array}$ & 41 & $\begin{array}{c}\text { October } \\
\text { 2018-March } \\
2019\end{array}$ \\
\hline Uruguay & Yes & Spanish & $\begin{array}{l}\text { Snowball and } \\
\text { convenience }\end{array}$ & Montevideo & 0 & 0 & 0 & $\begin{array}{c}\text { October } \\
2018\end{array}$ \\
\hline USA & Not applicable & English & $\begin{array}{l}\text { Convenience } \\
\text { and quota }\end{array}$ & Stanford, Florida & 100 & $\begin{array}{c}\text { Not } \\
\text { applicable }\end{array}$ & $\begin{array}{c}\text { Not } \\
\text { available }\end{array}$ & $\begin{array}{l}\text { March 2018- } \\
\text { September } \\
2019\end{array}$ \\
\hline Vietnam & Yes & Vietnamese & $\begin{array}{l}\text { Snowball and } \\
\text { convenience }\end{array}$ & $\begin{array}{c}\text { Ho Chi Minh City, Thanh Hoa, } \\
\text { Cam Ranh province, Lam } \\
\text { Dong, Mekong Delta area }\end{array}$ & 12.5 & $\begin{array}{l}\text { Not } \\
\text { applicable }\end{array}$ & 11 & $\begin{array}{l}\text { March-May } \\
2018\end{array}$ \\
\hline
\end{tabular}


Table S3. Model Fit Indices for the Factor Model of the Egalitarian Values in the Pooled Sample and in each Language.

\begin{tabular}{lcccccc}
\hline & $S-B \chi^{2}(1)$ & $p$ & RMSEA_SB & SRMR & CFI_SB & TLI \\
\cline { 2 - 7 } Arabic & 0.730 & .393 & 0.000 & 0.009 & 1.00 & 1.01 \\
Chinese & 0.076 & .782 & 0.000 & 0.003 & 1.00 & 1.02 \\
Dutch & 3.307 & .069 & 0.084 & 0.008 & 1.00 & 0.97 \\
English & 2.357 & .125 & 0.049 & 0.008 & 1.00 & 0.99 \\
Finnish & 2.903 & .088 & 0.035 & 0.005 & 1.00 & 0.99 \\
French & 2.810 & .094 & 0.026 & 0.005 & 1.00 & 1.00 \\
German & 1.469 & .225 & 0.040 & 0.019 & 0.99 & 0.96 \\
Japanese & 0.411 & .521 & 0.000 & 0.011 & 1.00 & 0.99 \\
Persian & 0.139 & .709 & 0.000 & 0.007 & 1.00 & 1.03 \\
Polish & 0.013 & .910 & 0.000 & 0.001 & 1.00 & 1.01 \\
Portuguese & 0.967 & .325 & 0.000 & 0.015 & 1.00 & 1.00 \\
Romanian & 0.274 & .601 & 0.000 & 0.007 & 1.00 & 1.04 \\
Russian & 0.009 & .924 & 0.000 & 0.001 & 1.00 & 1.01 \\
Serbian & 0.117 & .732 & 0.000 & 0.003 & 1.00 & 1.06 \\
Spanish & 4.234 & .040 & 0.045 & 0.010 & 1.00 & 0.98 \\
Swedish & 0.945 & .331 & 0.000 & 0.004 & 1.00 & 1.00 \\
Thai & 0.356 & .551 & 0.000 & 0.008 & 1.00 & 1.03 \\
Turkey & 1.020 & .312 & 0.009 & 0.007 & 1.00 & 1.00 \\
Urdu & 3.630 & .057 & 0.163 & 0.045 & 0.99 & 0.76 \\
Vietnamese & 0.210 & .654 & 0.000 & 0.003 & 1.00 & 1.03 \\
\hline
\end{tabular}

